\title{
Charles Mackay's own extraordinary popular delusions and the Railway Mania
}

\author{
Andrew Odlyzko \\ School of Mathematics \\ University of Minnesota \\ Minneapolis, MN 55455, USA \\ odlyzko@umn.edu \\ http: //www.dtc.umn.edu/ odlyzko \\ Revised version, February 26, 2012
}

\begin{abstract}
Charles Mackay's book Extraordinary Popular Delusions and the Madness of Crowds enjoys extraordinarily high renown in the financial industry and among the press and the public. It also has an extraordinarily low reputation among historians.

This paper argues that Mackay's sins of commission were dwarfed by his sins of omission. He lived through several giant investment manias in Britain, yet he did not discuss them in his books. An investigation of Mackay's newspaper writings shows that he was one of the most ardent cheerleaders for the Railway Mania, the greatest and most destructive of these episodes of extreme investor exuberance.

Mackay's story provides another example of a renowned expert on bubbles who decides that "this time is different." His moves through a sequence of delusions help explain the length and damage of the Railway Mania. He was a free market and technology enthusiast, and faced many issues that are important today, such as government ownership and regulation, interconnection, standardization, structural separation, and analogs to net neutrality. A crushing national debt and high unemployment in an economy pulling out of a deep depression (and in perceived danger of falling into another one) were very important in shaping attitudes towards railway expansion. The analogies and contrasts between Mackay's time and ours are instructive.
\end{abstract}




\section{Introduction}

Charles Mackay's book, Extraordinary Popular Delusions and the Madness of Crowds [27], first published in 1841, is famous for its depictions of irrational mass behavior. The popular press cites it extensively whenever there is concern about a potential new financial bubble. It is on the recommended reading list of the prominent investment bank Goldman Sachs [16], and a recent book used it as the basis for a collection of investment principles [42]. Bernard Baruch praised it highly, and apparently credited it with helping him sense market peaks ([18], pp. 95n, 252-253). Michael Lewis, known best for his colorful descriptions of Wall Street, included the chapters on financial manias from Mackay's book among his "Six Classics of Economics," thereby ranking Mackay with Adam Smith, Thomas Malthus, David Ricardo, Thorstein Veblen, and John Maynard Keynes [24].

Scholars who have investigated Mackay's book take a different view. Peter Garber found that in the treatment of the Tulip Mania, Mackay "plagiarized most of his descriptions from Beckmann [a German scholar of the late 18th century] with a little literary embellishment." Beckmann, in turn, relied on pamphlets written shortly after the collapse of that mania of the first half of the 17th century that "were motivated by a moralistic attack against speculation" ([11], pp. 29-30) but did not have solid, verifiable information. The more recent very thorough study of the Tulip Mania by Anne Goldgar similarly concluded that as a result of the extensive reliance in the literature on Mackay's account, "we are left with a picture of tulipmania based almost solely on propaganda, cited as if it were fact" ([15], p. 6). Still, Mackay's colorful style is appealing, and Ross Emmett, another recent scholar, wrote that Mackay's "tale reaches further than the facts, but that should not stop us from enjoying it" ([10], vol. 1, p. 2).

The history and status of Extraordinary Popular Delusions have been covered in some detail in [25], for example, and are reviewed briefly in Section 3. The role of this work in shaping popular perceptions and the reasons it became very popular have also been covered in the literature, for example in $[20,25]$.

The goal of this paper is to consider two points that have been overlooked in previous studies. One is the striking deficiency of Extraordinary Popular Delusions in not covering the great investment manias of 19th century Britain. The other is the role that Mackay himself played in stimulating and sustaining the greatest of these episodes of financial exuberance, the Railway Mania. The exploration of these two issues helps explain the size and persistence of the Mania. It also provides some interesting perspectives on the public policy issues of the 1840s, most of which bear close resemblance to modern ones.

Mackay (whose life and work are outlined briefly in Section 6), was born in 1814, and died in 1889. Thus he lived through the four great investment manias of 19th century Britain, that of the mid-1820s, followed by one in the mid-1830s, the Railway Mania of the mid- to late-1840s, and another railway mania in the mid-1860s. (They are sketched in Section 2.) Yet there is practically no trace of them in Extraordinary Popular Delusions, nor in Mackay's reminiscences [31,32].

In his lifetime, Mackay was known to the public best as a poet, the author of enormously popular song lyrics. If that was all he had been, the deficiencies listed above would be easy to excuse as natural for someone who loved language but did not care about industry 
and finance. However, Mackay was a journalist for most of his career, did some travel and investigative reporting, and for much of the 1850s, was the main editor of the Illustrated London News, which at times was the highest-circulation newspaper in Britain. He was also a prolific book writer, and published over 30 volumes of poetry, historical fiction, history, travel observations, and philology, as well as a pamphlet on street railways [30] that exhibits considerable knowledge of the technology and economics of urban transport. Thus it is puzzling that he did not write in some detail about the investment manias he lived through. He could not have been ignorant of them, and there are indeed a few passages in his books that mention them ${ }^{1}$.

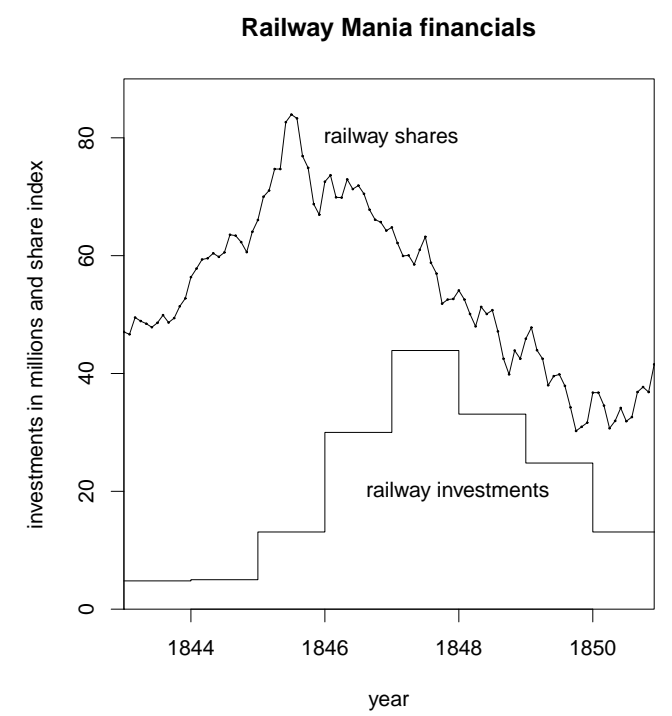

Fig. 1. Index of railway share prices in Britain and railway capital investments in millions of pounds sterling, 1843 through end of 1850.

The Railway Mania can be said to have started in 1844, and to have ended in 1849 , when the railway share market hit bottom. (Background information on this relatively little known by fascinating episode is available in [37]. Some information about its collapse is presented in [40].) Fig. 1 shows graphically the shape of this outburst of investor exuberance. The railway share price index in this figure is exactly one half of the index of [13], compiled on a monthly basis. Railway investment figures, which are known only on an annual basis, are taken from [35]. The GDP of the UK during that period was estimated to be in the range of $£ 460-600$ million [35]. Purely financial affairs, such as the Tulip Mania or the South Sea Bubble, involve astronomical valuations, much money changing hands, but little real economic activity, and usually collapse quickly. The Railway Mania was different. It lasted for about five years, and involved huge inflows of money from investors, inflows that stretched over the entire period. Total spending on actual construction (as well as legal fees, land acquisition, etc.) came to the equivalent of about $\$ 4$ to $\$ 5$ trillion for the United States today (compared to the size of the economy). Almost all of the funding was provided 
by individual investors, who included Charles Darwin, John Stuart Mill, and the Brontë sisters. At the peak of activity, in 1847, the army of railway construction laborers was about twice as large as the British Army ${ }^{2}$. It is easy to make the argument that this mania benefited the British economy as a whole, by providing the world's best transportation infrastructure. It has even been suggested that the boom in railway construction spending saved Britain from a revolution in 1848, when most of continental Europe went through a series of uprisings. What is not disputable, though, is that the Railway Mania was a disaster for large classes of investors. In late 1849, Charlotte Brontë wrote that "[m]anyvery many are - by the late strange Railway System deprived almost of their daily bread" ([48], p. 267). Nor did railway investor fortunes recover quickly. Half a dozen years later, the Economist of September 15, 1855, wrote that "[m]echanically or scientifically, the railways, with all their multiplied conveniences and contrivances, are an honour to our age and country: commercially, they are great failures."

In 1852, soon after the collapse of the Railway Mania, Mackay published a new edition of Extraordinary Popular Delusions, with substantial revisions. However, he chose to ignore almost completely this very recent bubble, whose wounds to investor finances and psyches were still raw. All we can find there is a footnote which says ([27], 1852 ed., vol. 2, p. 84):

The South-Sea project remained until 1845 the greatest example in British history of the infatuation of the people for commercial gambling. The first edition of these volumes was published some time before the outbreak of the Great Railway Mania of that and the following year.

Thus Mackay shared the widespread public perception that the Railway Mania was larger and more disastrous than the South Sea Bubble. But he did not provide any more explanation or detail.

We have no way of judging how important Mackay's activities during the Mania were in his decisions on what to cover in the 1852 edition of his book, or in later memoirs $[31,32]$, but he had a reason for keeping quiet about that period. At the peak of speculative excitement, in late 1845, he was among the Railway Mania's most enthusiastic cheerleaders.

Almost all newspaper and periodical literature of mid-19th century Britain was published anonymously, so we have no way to identify most of Mackay's output. However, there is one large body of analysis and editorial writing that we can confidently ascribe to him. Fortunately for us, it comes from the period that includes the speculative peak of the Railway Mania. In late summer of 1844, just as the railway fever was rising, he was recruited away from the Morning Chronicle, a famous London daily, where he had been a sub-editor, to be the editor of the Glasgow Argus, an influential although small newspaper in one of the largest cities in the UK. He served in that position until mid-1847, when a fierce political battle among the owners of the Argus resulted in his being forced out.

Among the most important features in newspapers at that time were the leaders, which were mixtures of editorial opinion, fact, and analysis. They were influential in shaping political, economic, and social discourse, and were sometimes written by the editorial staff and sometimes by outsiders. Based on what we know about the operations of the Argus, as sketched in Section 4, we can be confident that practically all the leaders and literature reviews published there during Mackay's tenure were not just approved by him, but were 
actually written by him. This will be assumed without any further comment in the rest of this paper.

To appreciate the atmosphere at the peak of the Railway Mania, in late 1845, it helps to read the short story "The Glenmutchkin Railway" [4], available online at many sites. It was the work of Mackay's fellow Scotsman and fellow poet, William Edmonstoune Aytoun. It is short, hilarious, and very informative. It features the memorable pair of protagonists, Augustus Reginald Dunshsunner and Bob O'Corkindale, who "abhorred [work] with a detestation worthy of a scion of nobility," and were eager to "[have] a pluck at the public pigeon." Its satire might seem thick in places, but in some cases reality exceeded even this inventive author's imagination. The heights of frenzy that engaged much of the population may be judged from a newspaper story about actual physical fights between the followers of the Duke of Montrose and the Marquis of Breadalbane, who were backing competing railway projects:

The present railway movement in the Highlands threatens to bring back the old lawless system which used to prevail in the more wild and mountainous districts of it. ... we hear it was a well fought battle, gallantly sustained by the engineers against fearful odds - where the assailants were ready, of course, to go to any extremity, after the Highland fashion, to "please the laird." 3

Aytoun wrote "The Glenmutchkin Railway" to warn of the folly and fraud of Railway Mania promotions. His story appeared in the October 1845 issue of Blackwood's Edinburgh Magazine. Just a few days later, Mackay published his most emphatic endorsement of the Mania ${ }^{4}$. On October 2, 1845, in a long leader entitled "The progress of railway speculation," which is quoted at greater length in Section 9, Mackay proclaimed that while "[t]he South Sea scheme was the mania of a deluded people," "[w]ith Railways the foundation is broad and secure. They are a necessity of the age ... destined ... to effect social and economical reforms of the highest value and importance, and to increase both individual and national wealth."

Many normally sober-minded people were expressing similar enthusiasm for railways. As just one small example, the inaugural January 21, 1846 issue of the Daily News proclaimed, as a non-controversial commonsense observation, that

What is good for the railways is good for the [British] empire, and vice versa.

But even among railway enthusiasts, Mackay was at the extreme fringe. At that time, Britain had approximately 2,000 miles of railways in service. The dominant view among both supporters and opponents of the Railway Mania was that the country would need 20,000 to 30,000 miles, roughly the length of its turnpike network. The only difference in opinion was how quickly construction should proceed. But there was a minority, which included Mackay, who claimed railways would spread well beyond 100,000 miles ${ }^{5}$. Even many strong railway supporters viewed such expectations as lunatic ${ }^{6}$. As it turned out, during the Railway Mania, Parliament approved railway projects for the construction of about 8,000 miles of lines, in addition to the existing 2,000. Of those 8,000 miles, just about 4,000 miles were actually constructed by the early 1850s, and the result was ruin for shareholders. (The British railway network did reach about 20,000 miles at its peak, but 
that was around 1920.) The basic reason, outlined in Section 2, is that railways cost more than expected to both build and run, and the demand for them was lower than expected.

While Mackay did not recognize the fatal (for investors) flaw of the Railway Mania, his attitudes towards railways did change, once the peak of speculative excitement in late 1845 passed. To explain this change, something has to be said about his political and economic positions.

As is sketched in Section 5, Mackay was a classic Liberal of the 1840s. In modern terminology, that meant (loosely speaking) that he was an extreme free market libertarian. He was a strong advocate of social and economic progress, which he believed would be best achieved through the untrammeled operations of the free market. He was also a technology enthusiast. With such a background, it was natural for him to be supportive of railways. But there were additional factors that made him susceptible to the lure of the Railway Mania. He was a strong nationalist, and railways were the product of British ingenuity and enterprise, and they promised to give Britain a commercial advantage in trade and manufactures. Perhaps most important, Britain, which had chronic problems of glaring inequality, illiteracy, unemployment, and malnutrition, had just emerged from a very long and deep depression. The wave of railway investments resulting from the mania of the mid1830s was being given varying degrees of credit for the economic recovery. The prospect of further railway expansion, with masses of laborers being employed at high wages, leading to massive spillover effects, was warmly received. The phrases "animal spirits" and "liquidity trap" were invented and popularized by John Maynard Keynes a century later, but the underlying concepts were understood well by the early Victorians, at least in principle. They talked about "fructifying" the idle capital of the country, for example.

Mackay's story provides insights into how bubbles develop and sustain themselves. Mackay was not a serious economist, not in the way that James Wilson of the Economist was, say. He was also rather gullible, as will be shown later. Still, he was one of the best informed people in Britain. He had personal connections throughout the British literary and press world, as well as in the Glasgow mercantile community. His job at the Argus also required him to sift through masses of other publications. Therefore he is an interesting person to study in trying to understand why the investment debacle of the Railway Mania took a long time to be recognized. It turns out that without ever abandoning his big delusion that railways were bound to be profitable, a delusion shared by most of his contemporaries, he fell under the influence of other delusions. Those delusions provided explanations for the difficulties the railway industry was encountering that distracted investors from the real problems. It is also likely that Mackay clung to his deep faith in the rosy future of railways because it enabled him to maintain his Liberal (i.e., extreme laissez faire) attitudes about the proper roles of government and private enterprise.

As was noted by Rande Kostal in his detailed study of the interactions of law and railways in Britain ([21], p. 214), "[t] he rise of the steam railway corporation in England punched a gaping hole in the prevailing liberal theory of markets." The issues that Liberals like Mackay faced were, except for names and specific technologies, basically the same ones we face today. Should a critical infrastructure that is a "natural monopoly" be left to the unfettered operations of the free market? Issues of interconnection, standardization, 
structural separation, and what we now call net neutrality, came up frequently in debates. So did proposals for government to provide financial support for the deployment of a new infrastructure in order to speed up general economic development. Mackay's encounter with railways did not "[punch] a gaping hole" in his personal belief in laissez faire approaches, but it did dent it. In particular, he called on the government to force railways to provide Sunday trains, and advocated eventual government ownership of the industry. How this happened, what exactly he had in mind, and how his other positions changed, is detailed in Section 10. (It appears that he was strongly influenced by the beguiling notion of using railway profits to relieve the oppressive burden of the gigantic national debt.)

This paper is based primarily on material published in the Glasgow Argus. The goal is to document Mackay's positions on issues related to railways and markets during the Railway Mania. References to the Argus are presented in an abbreviated form, with "GA 1846.03.12" denoting the March 12, 1846, issue, for example. If there is no other note, such a reference is to a leader in that issue (which was always on page 2 or 3 of what was almost always a 4-page broadsheet publication).

The next few short sections provide background information about the large investment manias of 19th century Britain, about Mackay, the Glasgow Argus, British press in general, and early Victorian attitudes towards progress. Section 8 relates an amusing incident involving the famous poet William Wordsworth, and Mackay's strenuous attempts to counteract Wordsworth's anti-railway activities. It serves to demonstrate Mackay's enthusiastic embrace of the technology that appeared to be revolutionizing social and economic life. Sections 9 and 10 are the heart of this paper. Section 9 presents the evolution of Mackay's attitudes towards railways as an investment. Section 10 discusses how those attitudes interacted with his views on public policy towards railways and about markets in general. The paper ends with a brief conclusions section, which summarizes Mackay's story and its relevance for the future.

\section{Investment manias in 19th century Britain}

Modern literature has copious coverage of the Tulip Mania, the South Sea Bubble, and the Mississippi scheme, the famous bubbles of the 17th and 18th centuries which were covered in Mackay's book. There is very little, on the other hand, about the large British investment manias of the 19th century, which are in many ways more interesting. The earlier manias involved practically no economic activity, just money changing hands, and extravagant hopes for easy riches being raised and then demolished in just a few months. Those of the 19th century, on the other hand, lasted for several years, and involved huge real capital investments. The fictional Glenmutchkin Railway, with shares of $£ 20$ each, and a $£ 1$ deposit per share, was representative of British projects of that period. Shareholders put down a deposit, and then, as the venture proceeded, and needed more capital, responded to "calls" from management, to provide more money (up to the specified limit, £20 for each Glenmutchkin share, for example). Many of the ventures floated during the exuberant periods folded (as the Glenmutchkin line does in the story) without calling for more than the initial deposit. But those that survived required, in aggregate, enormous inputs from investors. Fig. 1 shows this dramatically, with railway shares going down relatively steadily 
for about four years from their peak in mid-1845, yet railway investment mounting to its peak in 1847, when it was about three quarters the size of the national budget. Even at the bottom of the share market in early 1850, investments were far higher than in 1845 .

The British mania of the mid-1820s is surveyed briefly in [37]. It involved real capital investments of about $£ 18$ million in joint-stock companies, most prominently for mines in Latin America, and $£ 25$ million for loans to foreign governments, again largely in Latin America. The total, £43 million, was slightly over $10 \%$ of British GDP of that period, comparable to $\$ 1.5$ trillion for the U.S. today, and was regarded by the British public at the time of the Railway Mania in the 1840s as an almost complete loss.

The mania of the mid-1830s is covered in some detail in [37,38]. It involved real capital investment, almost exclusively in railways, of about $£ 70$ million, comparable to $\$ 2$ trillion for the U.S. today. It has been unaccountably neglected in the literature, in spite of several noteworthy features. As was pointed out for the first time in [38], it appears to be the unique example of a gigantic investment mania that succeeded. The share prices visible in Fig. 1 for the early period 1843-44 reflected returns to those who invested in the mid1830s that were higher than the risk-free government bond yields. What little has been written about this mania by such famous economists as Bagehot, Juglar, Rostow, and Schumpeter is incorrect or at least seriously incomplete. They typically considered only the early collapse of share prices after the most ebullient phase of this episode, and were unaware of the extended period of heavy capital investment and the eventual high profits. However, the investors of the Railway Mania were very conscious of what had happened during the preceding period. The nice profits resulting from that earlier period of extreme exuberance were the foundations for their belief they could make money from the new wave of railway construction visible in Fig. 1.

The fourth, and final, gigantic investment mania of 19th century Britain was the railway mania of the mid-1860s. Investment in this industry between year-end 1860 and yearend 1870 reached $£ 180$ million [35], about $20 \%$ of the GDP of the UK of that time, so comparable to $\$ 3$ trillion for the U.S. today. It is not known what Mackay thought or wrote about it. Nothing more will be said about it here.

The Railway Mania, pictured in Fig. 1, and the subject of this paper, was the third and greatest of the four large investment bursts in Britain in the 19th century. It involved real capital investments, from year-end 1843 to year-end 1853, of about $£ 180$ million, comparable to $\$ 5$ trillion for the U.S. today [35]. Information about its early stages is available in [37], and about the final collapse in [40]. The low railway share prices shown by the index in Fig. 1 at year-end 1850 continued throughout the 1850s, corresponding to the poor financial performance of the industry. The quote from the Economist of 1855 in the Introduction, that railways were "commercially ... great failures," was motivated by the miserable payouts. Investors bought shares in hopes of getting $10 \%$ dividends at a time when risk-free government obligations paid about 3\%, and good, stable companies were expected to pay about $4 \%$. Instead, dividends on railway common shares averaged about $2.8 \%$ over the decade 1849-1858, according to one estimate ${ }^{7}$. These poor results were the result of construction and operating costs that were higher than projected, while revenues were lower than expected. (See [40] for details and references.) 
A few words deserve to be said about the British financial environment of the 1840s. It has some instructive similarities to the current one, in which most of the industrialized countries face staggering debt burdens. There are frequent claims that once a country's debt exceeds $90 \%$ of GDP, it faces serious financial risks. Britain emerged victorious from the Napoleonic Wars in 1815, but with a debt that was far more onerous. It was over twice the country's GDP, a level that is currently attained only by Japan. By the late 1840s, that figure was down to around $150 \%$ of GDP. However, the economy was still primitive, in the early stages of the Industrial Revolution. Hence taxes, although regarded as the world's highest and barely tolerable, brought in only about 10\% of GDP to the national government (and another $2 \%$ to local ones). Therefore debt was about 15 times the annual spending by the UK government, as opposed to perhaps 7 times for Japan today. Interest on the debt took about half of the national budget, or around £28 million per year. The burden of this debt was a national obsession, and figured heavily in almost all policy discussions.

The final point is that the Railway Mania was predicted by many, although it does not appear that anyone had an inkling of just how big it was going to be. As Britain was emerging from the depression of the early 1840s, many observers were expecting railways to be the focus of investor enthusiasm. All other big speculations of the previous two decades (loans to Latin American governments, investments in Latin American mining companies and in British joint-stock banks, as well as loans to individual states of the U.S.) were viewed as disasters. The only exception were the railways of the 1830s. They were paying nice dividends. Further, investors appeared to have an exaggerated idea of just how profitable the industry as a whole was; as is usual in investment manias, perception outran reality. In addition, there was a widely perceived need for additional railway connectivity.

\section{The book Extraordinary Popular Delusions}

The extraordinary renown of this book is largely a recent phenomenon. Mackay himself did not appear to regard it as a major achievement of his life, as judged by the few and minor references to it in his two autobiographical works [31,32]. For more on the public perception of this work, see [25].

Mackay's book has had, and in various reprints, continues to have, several variant titles. The original publication took place in October 1841, and was of a two-volume work entitled Memoirs of Extraordinary Popular Delusions. In the Preface, Mackay wrote that should those two volumes "be favourably received," he would produce another one to cover some additional delusions. Apparently reception was sufficiently favorable to convince the author and publisher to rush the third volume into print, as it appeared around the end of $1841^{8}$.

Was the first edition of Extraordinary Popular Delusions a best-seller? The speed with which the third volume was produced suggests the first two did sell well. Altick [3] cites a reference that claims that 5,000 copies were sold in three days, which would have been spectacular for those days, when a typical first printing was around 1,000 copies. However, the reliability of the source is uncertain. Mackay mentions ([32], vol. 1, p. 100) that he received $£ 300$ for the three-volume work, which was not very high ${ }^{9}$. Still, this $£ 300$ figure is not inconsistent with high sales. It was common then for authors to settle for a flat upfront payment ${ }^{10}$. On the other hand, that the book may not have been too widely read 
is suggested by the fact that over the next few years it was advertised occasionally as if it were new ${ }^{11}$.

In 1852, a substantially revised two-volume version was published in a series of inexpensive books under the title Memoirs of Extraordinary Popular Delusions and the Madness of Crowds. That version, as well as the original, devoted only a fraction (about 150 out of over 1200 pages for the 1841 three-volume edition) to the coverage of the famous early financial manias, the Tulip Mania, the South Sea Bubble, and the Mississippi Scheme. The rest was devoted to a variety of other topics, such as duels, the "slow poisoners," the Crusades, witch hunts, haunted houses, alchemy, and Mesmerism. However, it is only the coverage of those early financial manias that retains interest, and is all that is reprinted in $[10,24]$, for example. With the brief exception of Mesmerism, which has some relevance in gaining an understanding of Mackay, that is also all that this paper considers.

Contemporary critics varied in their assessments of Extraordinary Popular Delusions. The Times complained (correctly) that it did not have a thorough and systematic study of popular delusions, while some other reviews were very positive ${ }^{12}$.

During the Railway Mania, Extraordinary Popular Delusions was rarely invoked as an authority $^{13}$. Skeptics frequently cited the early manias covered by Mackay, as well as the mania of the mid-1820s, but usually did not cite his book as a source. There was no need to cite it, as there was plenty of other information in print. For example, in 1840, William Smyth, a professor at the University of Cambridge [41], published his Lectures on Modern History [49], based on material presented to generations of students. This book, which went through five printings by 1848, provided much better, although briefer and less colorful, coverage of both the South Sea Bubble and the Mississippi Scheme than Mackay did.

\section{Mackay, the Glasgow Argus, and the British press of the $1840 \mathrm{~s}$}

Since many records of the Glasgow Argus survived, its operations and finances are known far better than those of most other newspapers of that era [7]. Some informative correspondence between Mackay and the owners of the Argus was also published after his departure ${ }^{14}$.

While it was influential, the Argus did not flourish financially. It had a circulation around 1,000 in the late 1830s, and this dipped down to 500 in 1843. In 1846, after more than a year of Mackay's stewardship, it was up to only $800^{15}$. Its most important local rival, the Glasgow Herald, sold almost five times as many copies that year. (The Herald and the Argus were both published twice a week.) These figures are very low by modern standards, but are characteristic of the provincial British press of the 1840s. Even London papers had small circulations. The weekly Economist sold about 3,500 copies of each issue. The Times, the dominant newspaper in the UK, sold more copies than all the other London dailies put together, but had a circulation of only about 30,000 in 1846. The low circulations did not mean low influence, though. Newspapers were written for the small middle and upper classes. They were expensive, and were often read in pubs, coffeehouses, and special reading rooms. It was estimated that a typical newspaper copy was read by between 5 
and 25 people (the wide gap in these estimates reflecting lack of any hard quantitative evidence). The Argus itself was important. Together with the Scotsman of Edinburgh it was "pre-eminent in Scotland" as "the spokesman of moderate Liberalism," and was a recognized organ of the 'Clique' that dominated Glasgow politics $[7,8]$.

General information about the operations of the newspaper press of the UK in Mackay's days is available in [17], for example. Much more detail about the Scottish press, including the history and role of the Glasgow Argus, is presented in [8]. Most provincial papers, and many London ones as well, had very small staffs. In the early years of the Economist, "apart from clerical help, the paper was virtually all written and put together by Wilson," the founding editor ([9], p. 25). The Glasgow Herald, which "was easily the most substantial newspaper property in the West [of Scotland]," had just one person in the editorial department, and one reporter ([8], pp. 141 and 171). Similarly, Mackay's 1844 contract provided that he was to "make up the [Argus] without the assistance of a sub-Editor, and shall have one reporter" (GA 1847.06.17).

At the major papers, leaders were sometimes written by the editorial staff and sometimes by outsiders. Even influential figures in politics (such as Brougham and Disraeli) as well as in intellectual life (John Stuart Mill and Henry Newman, who later became Cardinal Newman, for example) published leaders in the London papers. At these prominent press organs, the authorship of leaders cannot in general be ascribed to any particular person without some additional documentation (which is rarely available). For example, at the Daily News, a paper that started up in January 1846, Charles Dickens wrote only one of the 85 leaders published during his brief tenure as the first editor [46]. However, the Argus had neither the prestige nor the finances nor the need to attract contributions from outsiders. Hence it seems safe to attribute leaders and literature reviews to Mackay.

The Argus had a regular "London letter," common to many regional newspapers, whose origins and role are described in [8]. It was a gossipy account of politics, economics, stock exchange, as well as occasionally the theater and weather in the capital of the UK. In the Argus it was often very substantial, showing interesting insights as well as the ability of the authors (who appear to have changed from time to time) to gain access to influential people. It will be quoted several times.

Much of the Argus, as well as of other British papers, including the large and much more generously staffed London dailies, was devoted to material derived (copied entire or abstracted) from other papers. Charles Dickens first attained eminence as a reporter at the Morning Chronicle in the 1830s, where he worked with Mackay. In 1844, in a letter to another person he characterized Mackay as "poet"; and Sub Editorial, paste-and-scissorsorial Craftsman of the Morning Chronicle" ([52], p. 77). This may not have been meant to be denigrating. The quality of all newspapers depended heavily on the "paste and scissors" jobs of their sub-editors. At the Argus, Mackay was his own sub-editor, so the selection of what to publish from other papers reflected his judgment of what was interesting or important. As he explicitly noted (GA 1844.12.26, p. 4, "Railway intelligence" section), reprints from other papers did not imply endorsements of the opinions stated there. However, they do say something about the events, analyses, and opinions that Mackay thought were important, whether he embraced or opposed them. 
In his memoirs, Mackay wrote that he was able to write "untrammelled by the censorship of any literary or political superior" ([31], vol. 1, p. 404). This is confirmed by the records of the Argus. In spite of writing extensively on controversial topics, "[p] erhaps the surprising feature of [Mackay's] editorship was the lack of criticism of his advanced liberal views from the relatively conservative Whigs who controlled the Argus: for a party political organ with an impressive track record of editor-proprietor conflict, he appears to have enjoyed considerable independence" ([7], p. 91).

\section{Politics and economics: Liberals, libertarians, and progress}

The Tory, Whig, Conservative, Radical, and Liberal designations for political groupings of the early Victorian era were in some flux, and did not resemble modern ones. Mackay was a Liberal of the 1840s. This means that today he would be called an extreme free market libertarian. Another Liberal of that period was James Wilson, the founding editor and owner of the Economist, who is covered in some detail in [9]. They lived in perhaps the most laissez faire economy in history.

The most important issue for both Mackay and Wilson in the mid-1840s was the campaign against Corn Laws, which imposed tariffs on imported food. They won that fight, but they lost the war they waged against the Ten Hours' Bill. Passed in 1847, after several years of debate in Parliament, this law effectively limited the working hours in factories of children from 13 to 18, and of all women (but not of adult men!) to 10 hours per day. When even the House of Lords, the last hope for Mackay and his allies for blocking this legislation, voted in favor of the bill, he claimed it was "a Measure ... which all allow to be an experiment perilous, if not fatal, both to workmen and their employers, ... Mills are closing ...- - the operatives are thrown out of employment by thousands - they are clamouring for bread, ..." (GA 1847.05.20).

Both Mackay and Wilson were in favor of improving the lives of the poor, and viewed free markets as the best way to achieve this goal. When the new Royal Exchange building in London was opened, Mackay printed extensive news coverage of the event, as well as a long leader based on it. The initial passage of this stirring pean is worth citing as it expresses Mackay's faith in progress through free enterprise (GA 1844.10.31):

Our last paper contained accounts of the superb festival at the opening of the Birkenhead Docks at Liverpool, and to-day we publish full details of the still more magnificent ceremony of the opening, by her Majesty in person, of the New Royal Exchange at London. Both these events are splendid and gratifying, and in importance infinitely beyond the innumerable squabbles of rival factions, or the recital of the wars and jealousies of nations, which it is but too often the unpleasant duty of the conductors of newspapers to detail to the world. Both events bespeak the enterprise and the glories of trade; - of trade still young, vigorous, hopeful, and persevering; of British trade which has been the parent of European freedom, ... What but Trade has taken the scales of ignorance and blindness from the popular eye, and dispersed the light of mind over every portion of the habitable globe, ... 
Mackay's enthusiasm for technology could be seen already in his History of London of 1838. There he wrote about the Thames Tunnel, the "stupendous project," which was a "national work" that was "the wonder of Europe" ([30], p. 462). Although at the time of writing the tunnel was not finished, and in fact was "filled with water," Mackay expressed optimism about its eventual completion. It was indeed completed three years later, at a cost of about $£ 600$ thousand, more than three times the initial projections, comparable to $\$ 15$ billion for the U.S. today. It was a technological wonder that attracted throngs of tourists. It also provided great long-term benefits to society at large, as the shield technology it pioneered was the foundation for later underwater tunnels. But Thames Tunnel investors saw their stakes wiped out. Even the British government, which provided a loan that enabled completion of the project, recovered only a fraction of its stake. In 1845, Mackay's London correspondent called it "a monument of national folly" (GA 1845.10.30).

While Mackay was extreme in his enthusiasm for change, by the 1840s the view of economic and technological progress as necessary and desirable was very widely shared, even by the Conservatives. Thus in the leader welcoming the new year 1845, Mackay hailed a recent speech of Lord Stanley, a conservative minister in the Tory government of Sir Robert Peel for the claim that "No man in these days is allowed to stand stillimprovement must go on" (GA 1845.01.02).

While most Liberals supported new technologies such as railways as ways to speed up social change, some conservatives at times supported them as tools for preventing social change! For example, Section 10 shows how in early 1847, Lord George Bentinck and Benjamin Disraeli extolled railways as agents of economic development to forestall other measures for the alleviation of the Irish Famine. Thus support for the Railway Mania was not a strictly partisan matter, and came from all groups (as did opposition).

\section{Charles Mackay}

Charles Mackay was a minor literary celebrity. In 1850, when Wordsworth died, Mackay was mentioned, along with Tennyson, Leigh Hunt, Robert Browning, and Elizabeth Barrett Browning, as a potential succcessor as the Poet Laureate of the UK ([23], p. 145). (The appointment went to Tennyson.) On Mackay's death in 1889, there were numerous, extensive, and laudatory obituaries published in British papers. With time, however, his reputation faded, so that today only Extraordinary Popular Delusions is widely known.

Mackay left behind two sets of memoirs, written towards the end of his life [31,32]. As is true of most of the numerous other autobiographical accounts by British journalists late in the 19th century, they were written from memory, without serious research, so get some dates and details wrong. However, they do appear to be generally accurate, and are often cited for the insights they offer about British journalism and British society in general. But they do leave many questions about Mackay himself unanswered.

There are only two short biographies of Mackay available, in [41] and [56], in addition to some shorter treatments in [25] and in biographies of Marie Corelli [41]. Corelli illustrates nicely some of the large gaps in our knowledge of Mackay. She is another literary figure who is now almost forgotten. However, over several decades of the late Victorian era she 
was a phenomenally successful novelist. She had a strong connection with Mackay, who left his entire estate to her, cutting off his son ([43], p. 57). Still, in spite of research by several recent Corelli biographers, we still do not know whether she was Mackay's "adopted daughter, illegitimate daughter, or granddaughter" ([43], p. 231).

Next we consider three minor aspects of Mackay's life that shed some light on his attitudes, opinions, and working style. Extraordinary Popular Delusions has a chapter entitled "The Magnetisers," about the theory often called animal magnetism or Mesmerism. It was based on the idea that there was a certain ethereal medium residing in bodies of living beings, which could be used to effect cures or influence behavior. In spite of frequent debunkings, it experienced an upsurge in popularity in England in the late 1830s and early 1840s. In the original 1841 edition, the chapter on this topic is long and detailed, and concludes with ([27], 1841 ed., vol. 3, pp. 403-4):

In England the delusion of magnetism may for the present be considered as fairly exploded. ... Truth ere now has been elicited by means of error; and Animal Magnetism, like other errors, may yet contribute its quota towards the instruction and improvement of mankind.

In the 1852 edition, the corresponding chapter is far shorter, and does not discuss any of the English experiences and tests of Mesmerism in the 1830s and 1840s. The conclusion is far less emphatic: "[e]nough, however, has been stated to shew, that if there be some truth in magnetism, there has been much error, misconception, and exaggeration" ([27], 1852 ed., vol. 1, p. 295). This change in tone likely reflects a change in Mackay's opinions about the validity of Mesmerism. In his memoirs, he wrote that in the 1850s, he "believed to a certain extent in the physical phenomena of Animal Magnetism" ([31], vol. 2, p. 221). Mackay's change of heart probably came from his adoption of his colleagues' beliefs. After being widely discredited by 1841, Mesmerism saw a rise in its acceptance in the mid-1840s. Dickens practiced it on his family and friends, and Harriet Martineau (another prominent writer of that era) provided testimonials for the technique. Mackay does not seem to have discussed Mesmerism in his leaders in the Argus, but there was some coverage in that paper during his time there that varied in the respect it paid to this technique ${ }^{16}$. We can therefore conclude that Mackay's interactions with Mesmerism show substantial credulity and willingness to follow the (intellectually fashionable) crowd.

The second point worth noting about Mackay is that in his first set of memoirs, he wrote that at the Morning Chronicle, he helped expose some frauds, in particular a star example of Mesmerism, "an impostor of the name of Alexis, who flashed upon the town, ... in 1844" ([31], vol. 2, p. 221). This means that Mackay was not just a "paste-andscissorsorial Craftsman," but that he occasionally did investigative work ${ }^{17}$. In later life, he did other investigative reporting, as well as travel writing.

The final point about Mackay concerns his business interests. In one of the leaders in the Argus, Mackay claimed not to have any railway investments (GA 1845.09.18). (He certainly did not have much money to invest, but the lack of funds did not stop Thackeray, for example, from losing a bundle in railway speculation.) However, he did have some slight entrepreneurial urges. At that time, there were no daily newspapers in Britain outside London, although there were a couple in Ireland. In early 1847, Mackay came up with 
a proposal for the Glasgow Daily Press, but had to abandon it for lack of support, and someone else started the first regular Glasgow daily a few months later.

\section{Railway financial projections and the direct line delusion}

Mackay was an optimist with an eye for opportunities in publishing, and in his planning for the Glasgow Daily Press he came up with some financial projections that at least a few of the owners of the Glasgow Argus found plausible and appealing ([31], vol. 1, p. 402). In his leaders about the railway industry, Mackay assured his readers that on the whole, railway investments were going to be profitable. But it is striking that he appears never to have supported this position with any quantitative arguments, as he did for his planned daily paper.

The flood of investments into railways was based on concrete financial projections. Not only that, Parliament until the spring of 1846 required the submission of detailed business plans for new projects. Those plans were subject to examination by opponents before Parliamentary committees (the "parliamentary contest" mentioned in the next-tolast paragraph of "The Glenmutchkin Railway"). There was a particular methodology that was accepted by Parliament, and that was highly regarded by the public. (See [37] for details.) Readers saw many references to this methodology in the Argus, especially in the extensive reports from hearings before Parliamentary committees on Scottish railways. (For the 1846 session, Mackay even arranged, at a heavy cost, to have special reporting on those hearings just for his paper [7].) As just one of many examples, an ad on the front page of the December 4, 1845 issue from the East Coast of Scotland Junction Railway, addressed to that line's investors, reassured them that "[t]he measures for ascertaining the Traffic have been now so far matured, as to show that the Local Traffic alone far surpasses the extent on which, from general knowledge, the promoters calculated when the undertaking was commenced." This passage by itself clearly implied that early projections had been rough ones, made by the promoters, but that some systematic methodology was being applied "for ascertaining the Traffic," a methodology that investors were apparently expected to know about and to trust. Yet Mackay, in common with most of his contemporaries, did not discuss this methodology, nor investigate how well it had done in the past, nor ask whether it could be relied upon at the time of the Mania.

It is intriguing that some important questions were investigated carefully. For example, the issue of railway gauge was widely discussed, as will be noted in Section 10. A Royal Commission was even set up to solicit expert opinions and come up with recommendations. Similarly, atmospheric railways, a potentially disruptive technology, was subject to experiments and debates in both popular and technical press, and a Select Committee of the House of Commons was appointed to investigate it. In neither case were the conclusions of the two government bodies definitive, but they did provide much technical data to inform investors and policy makers. But those were the "known unknowns."

The accuracy of demand forecasts was one of the major "unknowns" that investors assumed they "knew." Unfortunately, what they "knew" was false. That is, it was a blindingly obvious issue that they assumed did not have to be investigated. There were no calls for Parliamentary committees or other bodies to look into the issue, not even any debate in 
the press. The size of the eventual railway network was yet another example. Back in the early 1840s, when the railway industry was completing the construction of its first 2,000 miles, share prices were depressed, and there was wide anxiety whether too much had not been attempted. But by the time of the Railway Mania it appeared almost everybody felt that at least 20,000 miles would be needed and would be profitable, with a substantial minority that included Mackay arguing for 100,000 miles or more. But there was no discussion or investigation of this issue.

The irrational behavior of investors and observers such as Mackay is demonstrated very convincingly by their embrace of so-called direct railways. These were lines that were meant to connect pairs of cities or towns by routes as short as possible, avoiding detours through other major points in the area. (They can be thought of as forerunners of modern bullet trains.) They were based on the conviction that most of the demand was going to come from traffic from one end of the line to the other, and that minimizing travel time was paramount. They were very prominent in the promotions of 1845 . (The fictional Glenmutchkin Railway is actually called, in the "prospectus" and also in the final paragraph of the story, the Direct Glenmutchkin Railway.) The few direct lines that were built turned out to be financial failures. That they were bound to be failures was easily predictable. Widely available statistics showed that most railway trips were short (about 15 miles in the year ending in mid-1845). Dionysius Lardner appears to be the person who most thoroughly demonstrated in print the main fallacies of the Railway Mania. He provided extensive and explicit statistics on this topic in the survey he published in late 1846 [22], and wrote that

"[i]t is clear, then, that the terminal populations have but little connexion with the financial success of railway projects. The main support is short traffic." Interestingly enough, while this observations was widely reprinted, its implications for railway investment were ignored.

Mackay was among those enamored of direct lines. (Even some opponents of the Mania, such as James Morrison, who shows up in Section 10, and The Times, were also blind on this topic and supported direct railways.) In none of Mackay's leaders is there any sign of recognition that this was a delusion. His London correspondent was also a supporter of direct lines, including the notorious Direct London and Exeter Railway (GA 1845.09.29 and 1845.10.02). However, after the most extreme enthusiasm died down, he did make some fun of their excesses. In the January 19, 1846 issue, he related how an engineer friend of his remonstrated with a secretary to a railway in Wales, that the projected line had the disadvantage that it "goes right over the top of Snowdon [the highest mountain in Wales]." The secretary reportedly responded "That is nothing, my dear Sir, compared to the disadvantage which we would labour under if the line was not advertised as a direct one!"

\section{Mackay, Wordsworth, and railways}

Mackay's attitude towards railways is illuminated by an incident that took place soon after he arrived in Glasgow. It involved William Wordsworth, who at the time of the Railway Mania was the Poet Laureate of the UK, and in the twilight of his career. Wordsworth had always emphasized the beauty of the natural world, and tended to contrast it with the crass materialism of human society. Still, he seemed to accept some change, even if 
grudgingly. In 1833, in the very early days of railways, he wrote the poem "Steamboats, viaducts, and railways" that presented technology in a positive light ([55], p. 573). In 1844, as the Railway Mania was inflating, the Kendal and Windermere Railway was proposed to enable easier access to the Lake District. Apparently Wordsworth was an early supporter of this scheme ${ }^{18}$, but then turned against it. He penned the famous sonnet, "On the projected Kendal and Windermere Railway," ([55], p. 664), which was printed in the London daily Morning Post in October 1844, reprinted widely in other papers, and is often cited today as an example of the early Victorian unease with technology:

Is then no nook of English ground secure

From rash assault? ...

$\ldots$

Speak, passing winds; ye torrents, with your strong

And constant voice, protest against the wrong.

Mackay reprinted the poem, but prefaced it with the passage (GA 1844.10.21, p. 4):

We copy the following singular and most recent effusion of the venerable poet laureate from the Morning Post, which appears to have been favoured with it as the representative of the stand-still or slow system, both in politics and travelling. Who can help wishing that a poet who writes so beautifully, and has such fine sympathies, should not take more enlarged views? Surely the great power of steam is as poetical and as magnificent an agent, if rightly considered, as "the passing winds and torrents" that he invocated - a power which is the servant of civilisation, and has done so much, and will yet do so much more, for the physical happiness and improvement of mankind. Would the laureate be grieved that thousands upon thousands of human beings, pent in populous cities, who have never been able to feast their eyes upon those glorious scenes he so well describes, should enjoy that delight, and that the railway should bring the lovers of nature to worship at its shrine? Would Winandermere (sic!) suffer if human beings had more facilities to behold its charms? or does pleasure shared grow less?

Over the next month, he reprinted several attacks on Wordsworth, including a poem by the writer and politician Richard Monckton Milnes ${ }^{19}$. When Wordsworth published two letters in the Morning Post, continuing his opposition to the Kendal and Windermere Railway, Mackay wrote a long leader, "The poet laureate upon railways" (GA 1844.12.19). He accused Wordsworth of being narrow-minded and selfish, and claimed it was "a pity that he had no friend to tell him that his sonnet was quite enough, and that no long letter was required to perpetuate the ridicule which would otherwise have died away."

Why did Mackay pay so much attention to Wordsworth? In the words of a biographer, "Mackay believed passionately that poetry conveyed truths superior to those of political economy [and] had an exalted view of his own calling as poet" [41]. Therefore he likely viewed the opposition of a poet of Wordsworth's stature and ability as a serious threat to the cause of railway expansion, a cause that he cherished. 
Wordsworth's opposition to the Kendal and Windermere Railway proved unavailing. This line was sanctioned by Parliament in 1845, and was built and placed in service. However, as with almost all Mania lines, it was financially disastrous for its shareholders. Had Wordsworth devoted some effort to investigating the commercial prospects of the line and demonstrating it would not pay, he might have succeeded in stopping it ${ }^{20}$.

While he attacked Wordsworth for opposing a particular railway in the name of preserving natural beauty, Mackay himself was vociferous in opposing some Glasgow railway projects in the name of aesthetics. This will be demonstrated with some quotes later.

\section{Mackay and Railway Mania investments}

This section concentrates on Mackay's opinions of railways as investments during his editorship of the Glasgow Argus from mid-September 1844 to the beginning of June 1847. While he was aware of some opinions that such investments might not be profitable, and reprinted a few in the Argus, he appears never to have wavered in his belief that in the end there would be abundant profits. However, his attitude did vary with the circumstances, and on a few occasions he did advise his readers to delay their projects.

Mackay's positions on railways as investments cannot be fully appreciated without also understanding his Liberal (in the early Victorian sense of the word) attitudes towards markets and the proper role of the government in the economy, as well as the projections of what railways could contribute to solving various pressing fiscal problems. Such topics are discussed in the next section.

A few words need to be said about the annual cycle of political and railway activities and how they were reflected in press coverage. Parliamentary sessions in those days usually lasted for half a year, starting in late January or early February. Railway promoters in almost all cases wanted to obtain the right to force landowners to sell the necessary land, and also to obtain limited liability for shareholders. These two valuable privileges could only be granted by Parliament. Therefore the focus of railway activity, as far as public attention was concerned, tended to be on London in the first half of each year. (In "The Glenmutchkin Railway," at the end of the story, the narrator writes of how a large group of promoters and employees "emigrated to London," where they "fought for three weeks a most desperate battle," while enjoying "the many pleasant days ... spent in the metropolis at the company's expense.") Provincial newspapers reported on Parliamentary hearings involving railway projects in their area. But in order to be heard by Parliament, projects had to pass several hurdles. The first and most formidable hurdle was the deposit of plans by November 30. (In the Glenmutchkin story, "[b]y singular good-luck, the plans and sections were lodged in time.") Before that, each railway company had to be organized, obtain funding, and prepare detailed plans. The peak of activity and excitement among investors would come in October, and would quickly die down in November, as a project that had not obtained the right backing and funding by that point could not hope to complete the necessary plans for submission by the November 30 deadline.

Mackay arrived at the Glasgow Argus in September 1844. This led to perceptible changes

at the paper, with longer and more literate leaders, more attention paid to literature 
reviews, and the like. At the beginning, not much was said about railways in the leaders. On the other hand, there was substantial growth in coverage of railways in the news and ad areas of the paper. Reports of meetings of railway shareholders, public meetings to consider new projects, discussions of the new and controversial atmospheric railway technology, ads with prospectuses of new lines, or with bids for contracts, or with calls for shareholders to oppose particular moves of their managers, were all proliferating. Some of the smaller pieces started getting grouped into a "Railway intelligence" section. This increase in space occupied by railway-related material was not caused by Mackay's arrival, as it was general in newspapers in late 1844. It reflected the growing activity of the early stages of the Railway Mania.

The news stories about railways were generally very positive. (News reports in those days were in general often infused with far more editorializing than has been common in the late 20th century. Some of the tendencies of the recent press to mix fact and opinion that are often decried by traditionalists may just take us back to the situation of the middle of the 19th century.) Thus a mid-October 1844 story on the Glasgow Junction Railway, a project that, in its more mature form, Mackay would go to war against, to stop it from destroying the beauty of Glasgow Harbour, outlined the goals and tentative plans, and concluded by saying that "[s]hould it be possible to accomplish all these objects, we feel assured that the public will take a deep interest in the undertaking" (GA 1844.10.17, p. 2). There were occasional notes of caution. A short piece was reprinted from the business section of The Times giving statistics of the multitude of new lines being projected, claiming this showed "how very extensively the mania for railway projects has taken root, and how very cautious the public ought to be in participating in it, without making every possible inquiry relative to the feasibility of the several schemes brought before them." ${ }^{21}$ Overall, though, the impression was of a very prosperous country moving at full speed to build out a useful and profitable transportation infrastructure.

Aside from the attack on Wordsworth in December that was cited earlier, Mackay did not publish any significant leaders on railways issues in 1844 . On the other hand, in November 1844 we find an interesting review (which, like other literature reviews in the Argus of this period, it seems safe to ascribe to Mackay). It is of an article by the railway engineer William Bridges Adams [1]. Adams' policy recommendations (which were supported by Mackay) will be discussed in some detail in the next section. Mackay (GA 1844.11.07, p. 1) embraced Adams' work as

not only eloquent and full of a knowledge of the subject, but comes very opportunely, when the railway mania has again taken possession of the money market, and competition with existing lines, threatens great changes in the fortunes of those who have embarked their capital in them. Scarcely one-third of the railway schemes that have been advertised within the last six months, will, in all probability, be anything more than schemes; but within a very few years, we shall undoubtedly look back upon our present Railway development with wonder, that, in the year 1844, so little had been done for the completion and proper administration of this great source of public improvement. 
This review shows that Mackay, just like most of his contemporaries, was at this time rather cautious. Britain had just emerged from an extremely deep depression, and many people were astounded by the energy of railway promotion. Mackay's estimate that only about one third of the schemes that had been announced would be realized was too conservative. On the other hand, Mackay was optimistic about railway expansion in the long term. Overall, this review can be read as indicating that the reason Mackay did not devote space to railways in leaders is that he did not see any major problems that needed to be addressed. He railed against Sir Robert Peel's attempts to constrain the Scottish banking system, because that was a political move that could be fought politically. In railways, he almost surely saw the productive workings of the free enterprise system that was occasionally threatened by attacks by Wordsworth and a few other critics, but was moving in the right direction.

In greeting the new year of 1845, Mackay proclaimed that "the great questions of more instruction and more food for the people - the questions upon which all the rest turn," had not yet been faced by the ruling elite in a satisfactory way (GA 1845.01.02). Those were issues he later devoted much attention to, although he also covered numerous other economic questions, such as tariffs. But up until mid-September of that year, he was strangely silent about the Railway Mania, even as it was raging, except for opposing proposals for projects that would mar the beauty of Glasgow Harbour. On that topic he was vociferous. While proclaiming that he was not one of those "who oppose railways, merely because they are railways," he claimed, for example, that "the Glasgow Junction Railway is a mere outrage, having no necessity to palliate it, ..., and wantonly interferes not only with the beauty and convenience of the city, but with the prosperity of that harbour" (GA 1845.07.10).

While Mackay avoided railways in his leaders up until September of 1845, his London correspondent provided extensive coverage of this subject. This person was given quite a bit of space, and quite a bit of leeway to write pieces that often were similar to substantial leaders in scale and scope. Sometimes he discussed particular railway projects, or railway share prices on the London Stock Exchange, while at other times he wrote about policy issues. It could be that Mackay felt that the London letter provided sufficient coverage of railway issues so that he himself did not need to get into them in leaders. But he could simply have shared what appeared to be the general attitude of the British press in the first half of 1845, that railways were not pressing issues of public interest, just matters of private enterprise that were to be encouraged, but did not require special attention from the press.

Aside from leaders and the London letter, during this period the Argus had extensive coverage of railways. Ads, meeting reports, and reprints from other publications filled a growing fraction of the pages of this paper. While the overwhelming majority of the material was supportive of the Railway Mania, there was a noticeable sample of contrary pieces. As an example, The Times had for a long time been taking potshots at the railway industry. Most of that activity, though, was through its business column. In July, it went on the warpath against the Mania, with a strident leader that started with "Whence is to come all the money for the construction of the projected railways?" is a question which at the 
present day we often hear familiarly repeated. ... The pace of railway speculation has fairly outrun the power and control of the Legislature; ..." From that point on, The Times used everything in its power to try to deflate the Mania (including reprinting the Glenmutchkin story in its entirety). Mackay republished this leader from The Times right away ${ }^{22}$.

As the summer of 1845 advanced, Parliament dispersed, having authorised the construction of about 2,700 miles of railways. At that point the UK had about 2,000 miles in service, and about 800 miles of new lines had been authorized in 1844. Those 3,500 miles of new railways from the sessions of 1844 and 1845 were supposedly going to be built for $£ 60$ million within three to four years. (The 2,000 miles already in service had cost about $£ 70$ million.) This figure is equivalent, as fraction of GDP, to about $\$ 1.5$ trillion for the U.S. today, so the expectation was of spending an amount comparable for the U.S. to $\$ 400-500$ billion per year over the next few years. By comparison, the construction of the Panama Canal, which took just about a decade, cost the U.S. government the equivalent of about $\$ 150$ billion in today's money in total, compared to GDP. The Interstate Highway System, which took 35 years to construct, absorbed (after adjusting for inflation) about $\$ 450$ billion in current dollars. Thus the 3,500 miles of additional UK railways were expected to absorb resources comparable to building a new Interstate Highway System, or three Panama Canals, and do it in each of several consecutive years! But the Railway Mania was still inflating, and was generating a new, even larger wave of projects. At the end of August, Charles Dickens wrote in a letter that "London is as flat as it can be. There is nothing to talk about, but Railroad shares. And as I am not a Capitalist, I don't find anything very interesting in that," ([52], p. 361). Others, though, including many who were not exactly "Capitalist[s]," such as John Stuart Mill and Thackeray, did plunge into the markets. Many people, inspired by dreams of easy riches, found the action not just interesting, but all-absorbing.

To some observers, especially The Times, this was dangerous insanity. But others found this activity inspiring and exhilarating. For example, the Morning Advertiser, a London daily, wrote in a piece that Mackay reprinted in the Argus (GA 1845.10.27, p. 4):

There are 30,000 miles of turnpike roads in the country, and there are, at present, only 6,000 miles of railway. It is quite evident, therefore, that in the making of lines which are wanted, and for which bills will undoubtedly be obtained, there will be employment for the people, at the very lowest calculation, for the next ten years. What a glorious prospect for us in this! We are at peace with all the world, and likely to be so; and at home we shall have a thriving and flourishing population, fully employed and, as a necessary consequence, well fed, well housed, and well clothed.

Mackay finally broke his silence (in leaders) on railway expansion in the September 18 issue, when he wrote:

We have hitherto avoided all notice of the extraordinary movements which have recently been going on among our more immediate fellow citizens, as well as mong the rest of the speculative and money-loving throughout the country; and if we approach the subject now, it is not without diffidence. We happen, however, to 
have some sources of information, relative to Scottish railways, which may not be patent to many of our readers, ... It is due to truth and common sense to conclude that [early railways] bore the usual impress of immaturity, or, it may have been, of error, and that time, and research, and experience, will produce their usual resultsimprovement, economy, augmented profits to the projectors, and increased benefits to the public.

He then went into a long analysis and a series of recommendations. There was not even a hint of concern in them that the new railway projects were in danger of being almost uniformly ruinous to their investors.

Mackay's enthusiastic leader was slightly counterbalanced by the "Railway intelligence" section in that same September 18 issue. It consisted of two pieces. One was drawn from a letter published in The Times, warning that the country simply did not have the resources to build even all the railways that had already been sanctioned by Parliament. The other was a leader from the Leeds Mercury, one of the few pieces from that period that warned (although without quantitative arguments) that many of the projected railways might be unprofitable ${ }^{23}$.

Mackay continued providing space and occasionally even positive words for some voices opposing the Mania. For example, soon after the Glenmutchkin story appeared, he praised it in a review: "The best, or at all events the most attractive article in this month's Blackwood, is, "How we got up the Glenmutchkin Railway," the production apparently of a Glasgow man, and most certainly of a very graphic and humorous writer" (GA 1845.10.09, p. 4). There were also reprints of more serious warnings, besides the two from The Times and the Leeds Mercury that were mentioned above. However, such pieces were rare, and Mackay did not accept them as valid. His most detailed overall evaluation of the Railway Mania came in the long leader "The progress of railway speculation" (GA 1845.10.02) that was quoted briefly in the Introduction. It is his fullest and most emphatic endorsement of the Railway Mania, so it is cited here in a longer excerpt:

We think those who sound the alarm of an approaching railway crisis have somewhat exaggerated the danger. It may appear wise to the careless or to the ignorant to trace resemblances between the South Sea mania of our own country and the Mississippi madness of the French in the last century, and the Railway mania of the present day, and to augur for the latter the same disastrous results as attended the two former. Those, however, who look more deeply into the matter and think for themselves cannot discover sufficient resemblance of cause to anticipate a similarity of effect; but, on the contrary, so much difference as to lead to the very opposite conclusion from that reached by the alarmists. It cannot be denied that, amid the multiplicity of schemes which every day brings forth, too many are concocted and buoyed up for a short period by men of straw; that many are fraudulent, and instituted for merely stock-jobbing purposes, and that sooner or later a day must come when the bona fide holders of shares in such project must incur heavy loss, and perhaps ruin. But, allowing their full weight to all these drawbacks, we think it is equally undeniable, that railway extension has rightly occupied the attention of the people of this country, and that we ought not to expect or wish for any diminution 
of the present excitement until the length and breadth of the land is ribbed with iron, and horse and coach traffic has entirely disappeared.

The South Sea scheme was the mania of a deluded people - was founded upon no solid, but altogether an imaginary basis; and when it fell, it left scarcely a vestige of property behind to atone for the wide-spread mischief it occasioned. ... With Railways the foundation is broad and secure. They are a necessity of the age. They are a property real and tangible in themselves, and they must of necessity increase and lead to still further and more beneficial developments as soon as they have passed that period of infancy, strong though it be, in which every man who can look before him cannot help feeling them to be. Success to them must be the desire of every friend of humanity; and both the quiet philosopher and the active man of business can perceive that there is not a more noble, or a more advantageous employment of British capital than in these projects; - destined as they are to effect social and economical reforms of the highest value and importance, and to increase both individual and national wealth. ...

... we think the alarmists are in error, and that there is no reason whatever to fear for any legitimate railway speculation - or that the country has miscalculated its own strength in entering with so much vigour and enthusiasm into so many grand schemes of internal improvement.

A more ringing endorsement of the Railway Mania could hardly be imagined. The embrace of continuing rapid railway expansion until "horse and coach traffic has entirely disappeared" placed Mackay at the extreme fringe among Mania enthusiasts, as was noted in the Introduction. It meant he expected the network of rails to spread over 100,000, or 200,000, or more miles. And this was all to be done with profit for the investors!

The leader cited extensively above was followed by another in that same issue on Scottish railways, part of a series that started with the one on September 18 that had been mentioned earlier, and continued through early December ${ }^{24}$. It is hard to tell just how sound they were ${ }^{25}$. However, they contained very detailed and emphatic evaluations and recommendations for railways in Scotland. They were based on a clear vision (although not one expressed in quantitative terms) of what the profitable flows of traffic were likely to be. This must have been the result of much careful thinking about the issues, and attendance at various railway shareholder meetings. There are three points about them that are worth noting.

It is rather intriguing that Mackay did show some sense of moderation. Aytoun, in a brief preface to the republication of "The Glenmutchkin Railway" in 1858, wrote that although this line "was purely imaginary, and was not intended by the writer to apply to any particular scheme then before the public, it was identified in Scotland with more than one reckless and impracticable project; and even the characters introduced were supposed to be typical of personages who had attained some notoriety in the throng of speculation." This is confirmed by the Thomas book [51] about the Callander and Oban Railway. That line was built decades later, but can be regarded as a successor to one of the abortive projects of the Railway Mania for the West Highlands that were identified with the fictional Glenmutchkin Railway. While Mackay did not denounce those lines explicitly, his detailed 
recommendations and evaluations of the railway industry suggest by omission that he did not regard the West Highlands projects as promising. He divided Scottish railway projects by geography, but his "Western Division" included basically only lines to the Southwest of Glasgow. He did not discuss any lines to the Northwest, past the Loch Lomond area, such as the Scottish Western Railway. This line, advertised in the Argus of August 11, 1845, on page 1, for example, was to run all the way to Oban, and among its chief backers was James Lumsden, the Lord Provost of Glasgow, and one of Mackay's chief allies among the owners of the Argus in the political struggles that were to come in $1847^{26}$. Mackay was familiar with that part of Scotland. In his memoirs, he wrote ([31], vol. 1, p. 248) that the Argus job offered "the additional advantage - a very great and delightful one to me - of contiguity to the sublime scenery of the West Highlands, to which I could resort from Saturday to Monday, away from the closely crowded and smoky city, to the breezy moorland and the mountain top - to lake and glen, and rapid stream - to all the rugged grandeur of Loch Long, and the softer magnificence of Loch Lomond." As a result Mackay probably sensed that the demand for railway service in that area was likely to be low, and so was not swayed by any rosy revenue estimates. But he did not write anything about this explicitly.

The second point worth noting is that railways were a distraction from Mackay's main obsession at the end of 1845 . The poor crops of that year led to an upsurge of political activity by the free traders, including Mackay. There were large public meetings calling for "the opening of the ports," petitions to Parliament, and fiery leaders in newspapers. One could write an article just about the popular delusions surrounding the Corn Laws. Activists on both sides, such as Mackay, wrote in apocalyptic tones. Yet more sober observers managed to remain restrained. As an example, John Ramsay McCulloch, a very prominent economist of the era, and a confirmed advocate of free trade, had earlier that decade considered the subject in view of available statistical data [33]. He argued convincingly that abolishing Corn Laws would have only a modest economic effect. (This proved to be true, for references to some modern literature on this topic, see [47]. The struggle over the Corn Laws may have been important as an indicator of how far and fast the liberalization of the economy would go, but by itself did not deserve all the heat that was generated.) Mackay was heavily involved in the agitation, and this clearly took much of his time and energy. That he still devoted considerable effort to railways proves that he regarded them as important.

The third point about Mackay's evaluation of Scottish railways will be discussed in the next section. In the heat of excitement, Mackay abandoned his earlier concerns about monopoly.

The final and most exuberant stages of the Mania in 1845 abound in transparent delusions that should have been seen as such right away. For example, there was a Railway Press Mania that led to the springing up of numerous railway papers, including two daily ones. This mania was fed by the flood of railway advertising money. But just on the basis of what had happened in previous years, as well as the institutional framework, it should have been clear that most of this ad funding would dry up by the beginning of November, and much of the rest by the beginning of December (possibly to revive again the next fall). 
But most of the people involved in these ventures seemed to be blinded by the excitement and huge flows of money, and rushed to create new publications that soon (sometimes after just a couple of issues) had to fold ignominiously.

At the end of 1845, railway share prices crashed. Poor harvests, combined with anticipation of increased demand for money for railway construction, led to an increase in interest rates. Further, and likely even more important, railway promotion for that year simply ran out of time. Projects that could not get the funds, the provisional committees, the engineers, the surveyors, etc., all lined up and working early enough to deliver the required plans by November 30, were simply out of the running for consideration by Parliament in the 1846 session. And once the rush atmosphere dissipated, the hope of easy riches through sales of shares to a "greater fool" vanished, and people started to reflect on what they faced. Shareholders were in possession of extremely leveraged futures, in modern terminology. The fictional Glenmutchkin Railway investors (scripholders, to be precise) had paid $£ 1$ per share if they got in on the original allocation, and possibly more, if they bought in the open market, and were now legally bound to provide additional $£ 19$ per share if the project passed Parliament and proceeded. This led to regrets, including a few suicides, and many more hasty departures for foreign countries, as debtors' prisons were ubiquitous. There were instances of shares being sold at negative prices, with the seller paying the buyer to avoid the onerous obligation of having to come up with the extra funds. Markets were going down, and, as usual, the leverage that worked to make the world seem rosy on the way up, was wreaking its destructive effects on the way down.

As railway share prices were declining, Mackay was reassuring his readers. In a leader, he claimed the blame for the declines should not be placed on the Bank of England, but on the Corn Laws, that opening the ports would revive confidence. He also reprinted, from the Leeds Mercury, 12 reasons "to believe that the crisis, though it may be severe, will be short." Of those 12, three related to railways: (i) established railways were solidly profitable, (ii) those under construction were going to be nicely profitable, and (iii) most of the projected railways might be delayed, and might need to go through mergers, but would be fine in the long $\operatorname{run}^{27}$.

On November 17, The Times published a detailed compilation of the 1,428 railways that had been registered (a preliminary step necessary to start raising money) through the end of October, with the capital each was expected to require. Prepared by W. F. Spackman, a prominent collector of economic statistics, this table showed that in total, railway projects were expected to cost an amount comparable to the national debt, which was huge, on the order of $150 \%$ of GDP of the UK, equivalent to $\$ 20$ trillion for the U.S. today. The list was accompanied by a long leader, which called it "a tale of national delusion," claimed that "[t]he mischief [had] gone too far already," and that "[w]ith so fearful a testimony to the speculative madness ... [one could] apprehend almost anything." Spackman's work caught the attention of the public. Years later, some people referred to the publication of those tables as the blast that blew the Mania apart. However, by November 17, most of the financial speculation had died down. The Spackman tables were based on public information, and rough estimates had been made earlier by others that were in the same 
ballpark. So those tables did not introduce any really novel information. But they appear to have met a need among the public for something to fasten their attention on.

Mackay did reprint the leader from The Times that accompanied the Spackman tables, with its emphatic message that "[t]he mischief [had] gone too far already" as soon as he could (GA 1845.11.20, p. 4), but even there he put a hint of a doubt in the introduction, saying of the Spackman work that it was "a long, and, to all appearances, a carefully prepared synopsis." In his own writings, he did the best he could to assuage his readers' concerns. The supporters of the Railway Mania viewed it as a healthy expression of British capitalists' "animal spirits," a triumph of private technology and private initiative. Railway Mania supporters' standard riposte to the accusations that too much money was going to flow into railway construction was to point out that far more money had been spent fighting Napoleon. If it had been worth wasting all those lives, materials, and money on destructive military activities, why was it not worth spending an appreciable fraction of the war funding on a productive and profitable infrastructure that would benefit the country in perpetuity?

At that time, the most prestigious publications were the quarterlies, with the Edinburgh Review, the Quarterly Review, and the Westminster Review at the apex of the hierarchy. The December 1845 issue of the last of these had an article by its editor, William Hickson [19], which, among other passages supporting railway expansion, had an elaborate version of the "war and railways" argument. Mackay reviewed that issue briefly (GA 1845.12.18, p. 4), and noted that the Hickson piece was especially important, and that

[t]he writer is entirely opposed to the alarmist views which have been expressed in influential quarters, and contends with great appearance of truth, that there was really nothing in the immense speculations in which we were engaged to justify any well grounded apprehension. The article is entitled to a careful perusal.

Ten days before, in a leader, the last in the series entitled "Scottish railways," Mackay presented an overview of the new railway projects in Scotland (GA 1845.12.08). At that stage it was known which ones had managed to clear the November 30 hurdle, and Mackay was proud how well the Scottish ones had done. Still, he recognized that many of the plans that had been submitted were of poor quality, and might lead to rejection of the proposals by Parliament. So he strongly advised delay, returning the deposits to investors, and planning on redoing the plans more carefully the following year. He was also aware of the less ebullient atmosphere and the greater difficulty in raising money, as well as the extensive duplication among some groups of proposals. Hence he wholeheartedly "urge[d] mutual and friendly conference, mutual concession and prompt amalgamation." Thus, as in his earlier leaders about Scottish railways, at this point he still had no concern about railway monopoly. Overall, while he saw some need for caution, he conveyed a sunny outlook for railway investors.

The exuberant phase of the Railway Mania had ended around October 1845, and from that point on, air continued seeping out of the balloon, as evidenced by railway share prices in Fig. 1. But in any event, the creation of new projects was at an end (to be revived next summer and fall, according to almost everyone's expectations), and the action moved to London, where Parliament was to start the 1846 session on January 22. (Not coincidentally, that was one day after the Daily News, edited by Charles Dickens, came out with its first 
issue.) The 1400+ railway projects that Spackman found at the end of October 1845 had been winnowed. About 800 plans had been submitted by the first deadline of November 30, and then additional hurdles as well as mergers eliminated many of those. Hence by the time Parliament started serious consideration of railway bills in early February, there were about 550 left. (Eventually, 272 railway bills were passed in that session.)

The main concerns that were being expressed about railways at that time were (i) whether Parliament could possibly cope with such a giant flood of proposals, (ii) whether the money could be found to build the projected railways, and (of immediate urgency) (iii) whether the money could be found to pay the required Parliamentary deposits. The first two issues are easy to understand. The last, rather technical concern, is explained in the next paragraph. However, practically nobody was talking of the real fundamental problem of the Mania, namely that almost all of the projects were going to be ruinous for their investors. Could somebody have shown shareholders what would happen to the prices of their shares (as is visible in Fig. 1), they would surely have managed to shut down their companies and the three main public concerns would have become moot. But the essentially universal conviction was that abundant profits were awaiting those who managed to build out their lines.

Railway projects had to deposit substantial sums of money with the government just before Parliament started considering them. Mania skeptics, led by The Times, claimed that because of antiquated rules governing this process and the volume of new schemes, there was simply not enough money to even make the deposits, at least not without a serious disturbance to the financial system. In mid-December 1845, the Argus reprinted two pieces next to each other. One was from The Times, and claimed the projected railways would require deposits amounting to $£ 35$ million. The other piece, a rejoinder from the Morning Chronicle, claimed deposits would amount to no more than $£ 10$ or at most $£ 15$ million $^{28}$. A month later, in January 1846, Mackay, citing updated information about how many projects were still in play, did his own computations, with very dubious assumptions, and concluded in a leader that deposits would amount to $£ 6$ million, perhaps $£ 7.5$ million at the most extreme, and that Parliament would need to deal with at most 200 schemes (GA 1846.01.19).

In the end, railway deposits for that session amounted to just about $£ 15$ million $^{29}$. This was less than half of what The Times had threatened its readers with, and equal to the top estimate of the Morning Chronicle. But it was twice Mackay's extremal bound. The actual process went very smoothly, which even The Times had the grace to admit was counter to its predictions. (This paper in later years would acquire a legendary reputation for having single-handedly fought the Railway Mania. That reputation, though, ignored (i) many other skeptics, (ii) the many occasions The Times had been wrong, or at least seriously premature, and (iii) the fact that in almost all cases its warnings were based on incorrect arguments.) Further, Parliament had to process over 500 projects, not the 200 that Mackay had estimated. Thus this story shows Mackay doing his very best to paint as rosy a picture for railway investors as he could, even if he had to strain his readers' credulity. 
As the year 1846 started, the main economic issue, as far as public discussion went, was not railways, but the Corn Laws. Free traders such as Mackay had been getting more and more enthusiastic and active towards the end of 1845, and felt that the poor harvest provided just the clinching argument they needed for repeal of these restrictions on free trade. As was mentioned earlier, the volume and stridency of the arguments (on both sides) was astonishingly high. During Dickens' tenure as the editor of the Daily News, or a bit less than three weeks, 26 out of 85 leaders were devoted to the struggle against Corn Laws. As a recent observer ([46], p. 52) asked, "did it deserve 26 long, repetitive and tedious editorials full of exaggerated abuse of a law which in reality had little impact?" But to the participants in that struggle this seemed the key issue of the day.

Mackay was one of the standard bearers in the conflict. There were many fiery editorials in the Argus on this topic, as well as a series of poems, "Voices from the Crowd," that Dickens recruited Mackay to write for the Daily News. (They were also reprinted in the Argus.)

While Mackay, along with most people, was pre-occupied with Corn Laws battles, he did not forget railways. When, in mid-1846, he prepared the book Voices from the Crowd [28], which contained about three times as many poems as had been published in the series under that title in the Daily News, he included there "The poetry of railways," which ended with:

Blessings on Science, and her handmaid Steam!

They make Utopia only half a dream;

And show the fervent, of capacious souls,

Who watch the ball of Progress as it it rolls,

That all as yet completed, or begun,

Is but the dawning that precedes the sun.

But railways were clearly subordinate to free trade. In the first leader in the Argus for 1846 (GA 1846.01.01), he wrote how in the previous year,

... the whole energy of the nation was thrown into the idea of perfecting its railway communication. Never was there such a fury of road making; never was there such a plethora of money and of enterprise, ready to be directed towards the development of the internal communication and wealth of a country; never did science indulge in such glowing and golden visions, and form such high aspirations for the increase of human happiness by physical means, and never did the prospect seem so near of a total revolution in the tastes, habits, and modes of thought of a whole people. [But then came an excess of speculation and the poor harvest.] The great cause of the abolition of the Corn Laws immediately assumed a more urgent and fearful importance than it had ever assumed before. Men of every political party, who had been drawn into the vortex of railway speculation, saw at once how intimately the question of cheap food was bound up into every question of trade and commerce. They saw that if the country were to have its railways, the poor man must have his food; that if we were merely to complete the railways we had begun, there must be prosperity for trade; and that there could not be this prosperity when the whole of the labourer's wages were expended upon his mouth; ... 
Mackay was thus telling his readers that there was this wonderful railway system to build out, but if they wanted that task completed, they had to first abolish the Corn Laws.

As the year 1846 advanced, and a victory in the Corn Laws battle was becoming ever more apparent, Mackay began to turn his attention to other topics, including railway policy issues, as will be discussed in the next section. In particular, he finally accepted the warnings by The Times from 1844 and 1845, that too much was being attempted at once. In that he was joined by many other railway enthusiasts. The March 23, 1846 issue of the Argus had a detailed report on a public meeting held three days earlier in Glasgow. Attended by numerous businessmen, it passed resolutions calling on the government to slow down the approval of new railways in order to protect the economy. This was one of the earliest such meetings to be held around the UK over the next couple of years, as railway construction activity grew in scale to resemble a major war, and the accompanying disruption of the economy mounted. The March 23 issue also had a long leader "Past, present, and future legislation on railways." It paid the usual obeisance to free enterprise, by saying that "[n]othing can be more true, as a proposition, than that a Government should not interfere with private enterprise," but then said that "it seems equally true that Government should refuse to grant extra facilities to people who are attempting too much for their own safety and that of the public." Mackay noted in the leader that "it [would have been] no interference with the employment of capital - no tampering with the general industry of the country" if consideration of all new railway projects were deferred for a year. After all, what railway promoters were asking for was not to be left alone, but for Parliament to allow them to interfere with landowners' property rights. Thus there was much scope for an industrial policy that would not damage the "animal spirits" of businessmen $^{30}$.

Various estimates were flying around as to how much it was safe for Britain to invest in railways per year, typically (among the skeptics) in the $£ 20$ to 30 million range. (See [37] for references and discussion.) Mackay did not cite a precise figure, but seems to have inclined towards the lower end of this range. In a leader in June (GA 1846.06.08), he claimed it was "capable of mathematical proof" that the country could not even afford to build the lines authorized by Parliament in 1845, a task that likely would have taken about $£ 20$ million per year. As it turned out, about $£ 44$ million was invested in railways in 1847 , demonstrating that Mackay's "mathematical proof" had serious flaws in it. Thus we can say that Mackay went from an extreme of optimism to an extreme of pessimism.

As the next section will show, in the spring of 1846, Mackay enthusiastically adopted several other notions, in particular that government ownership of railways would provide for a painless way to deal with the crushing burden of the national debt. All these notions were grounded in an extremely rosy view about the future of railways. Gross revenues of the railway industry in the UK were $£ 6.1$ million in 1845 , yet what was being envisaged was net profits exceeding the interest on the national debt, or about $£ 28$ million per year. Clearly the rail network would have to grow a lot, and be very profitable, for such expectations to be realized. Yet that appears to be what almost all people expected. Investors seemed to be fixated on the idea that railways would produce $10 \%$ dividends. James Morrison, one of the most prominent critics of the Railway Mania, was certainly convinced that is 
what they expected [36], and his fear was that they would achieve it. He was convinced that lower dividends were required to assure a healthy economy for Britain. But even he thought a 6-7\% profit rate was reasonable for railways, given the long delay between initial promotion and service, and the risks involved. The $2.8 \%$ that investors actually received in the 1850s was simply not on his or other observers' mental horizon.

The leader about railway policy from the April 23, 1846 issue of the Argus, which will be covered in detail in the next section, illustrates well Mackay's attitudes towards railways. In particular, it demonstrates his deep faith they would be profitable, since he expected and looked forward to a revival of speculation and a giant additional expansion of the railway system. But at that time he was beginning to despair about the immediate prospects. In the leader entitled "The railway mania" in the June 8 issue, he was predicting a wave of bankruptcies for the fall of that year. He wrote that "every one thinks other schemes may, and ought to fail, but that his own may, and ought to succeed; and so the whole posse of them are urged forward, until a new and more serious panic than the last shall blight all hopes, and cripple the resources of the nation for a whole twelve-month, if not longer."

The fall of 1846 passed by without any financial disasters (although the potato famine assumed a catastrophic form), and Mackay turned back to an optimistic outlook on the immediate prospects of railway enterprise. At the end of 1846 he quoted from a monthly circular from a large trading firm, which, he said, was "written in a sound, cheerful, and manly style, and will prove an excellent antidote to the whinings of those who see nothing but gloom before us, and contrasts most favourably with the state of affairs at the close of last year" (GA 1846.12.07). In the first few months of 1847, however, the financial outlook started darkening. Mackay twice reprinted "alarmist" pieces from The Times. However, in both case he accompanied them with leaders refuting the dire projections, in one case writing that the reprint was just to warn the readers not to pay attention to "any similar croakings" from The Times (GA 1847.01.21 and 1847.03.15). When the financial crisis of the spring of 1847 did arrive (a crisis that was relatively minor compared to the famous one of the fall of that year), Mackay had to admit there was a problem, and implicitly seemed to allow that railways may have contributed to it, but argued that "[t]he railway mania and the potato famine [were] rapidly becoming things of the past" (GA 1847.05.10). He argued that the root cause was a faulty monetary system that had to be fixed.

That Mackay was totally unprepared for the dismal outcome of railway investments that is visible in Fig. 1 is shown by two leaders towards the end of his time at the Argus. In March 1847, he expressed faith that "another railway mania" would soon arise (GA 1847.03.04). (It actually took two decades to arrive, see Section 2.) But an even better example of his rosy views is offered by the last issue of 1846 (GA 1846.12.31). It had a long leader whose title, "Railways for the many and not for the few," as well as substance, were drawn from the recently published pamphlet of James Ward [53]. Ward was in principle in favor of government control of railways, so that their "vast" profits "would have accrued to the nation at large," instead of being "enjoyed by a comparatively small section of it." However, he decided that the opportunity for state ownership of railways had been squandered. As a second best option, therefore, he recommended that railway shares be made smaller. (The $£ 20$ shares of the Glenmutchkin Railway, which were representative of 
the new projects of the Railway Mania, were equivalent, on the basis of GDP per capita, to about $\$ 50,000$ for the U.S. today, and were meant for the really affluent ${ }^{31}$.) That way the common people could buy them and participate in those "vast" profits that he was confident would be earned by the lines already authorized as well as the many new lines he expected in the near future. (In the second edition of [53], published in the spring of 1847, and thus a few months after Mackay's leader, Ward explicitly predicted that most railways would earn $10 \%$ profits.) The financial debacle shown in Fig. 1 apparently was totally inconceivable to Ward, and to Mackay as well, who heartily endorsed Ward's views and recommendations.

\section{Mackay, the Railway Mania, the markets, and public policy}

The preceding section outlines Mackay's opinions of railways as investments. A fuller appreciation of them, though, requires an investigation of his more general views on the markets and on public policy.

The positive review in (GA 1844.11.07, p. 1) of the article by the railway engineer William Bridges Adams [1] shows that Mackay, along with many other Liberals of the time, did have some concerns about railways' effective monopoly on transport. British observers of the 1820s and 1830s were proud of their nation's canal and turnpike systems, the best in the world. A large part of the reason for their excellence was perceived to be that canals and turnpikes only provided the basic (monopoly) infrastructures. A competitive industry of carriers provided actual transportation services. Railways provided faster, more comfortable, and less expensive services, but they were becoming monopolies, and were ruining or taking over canals and turnpikes. This led to the types of abuses that Victorians knew to expect from monopolies. Adams proposed, among other points, that railway companies be forced to follow the model of canals and turnpikes, be barred from providing transportation services, and only own and maintain the rails. Mackay supported that idea. Private enterprise enthusiasts such as Adams and Mackay wanted to encourage the "inherent energy of the English people" (to quote the Adams article), and so were vehemently opposed to new burdens being imposed ex post facto on lines in operation. On the other hand, they were willing to support, in a limited way, Parliament setting conditions at the time charters were granted to railways. That was part of the grand bargaining process, and investors could accept or decline those conditions.

As the Railway Mania picked up steam during 1845, Mackay's concerns about the monopoly aspects of railways appear to have disappeared as he enthusiastically supported the whirlwind of activity. He poured scorn on the notion of "a self-contained railway," one that served just local traffic, which animated the early stages of railway expansion in the 1820 s and 1830s. Therefore he was an enthusiastic supporter of the creation of large systems that would serve long-distance traffic. He was also in general in favor of consolidation. He perceived competition between railways as absurd. He was concerned about some issues of market failure, where he felt the existing system did not provide proper incentives. For example, he concurred with the call for for new liability legislation by the Examiner ${ }^{32}$. In general, though, he was still a faithful adherent to the doctrine of laissez faire, and an unrestrained cheerleader for railway expansion. 
Once the peak of Mania excitement was passed, Mackay began to turn his attention to other topics, including railway policy issues. One of the most contentious questions of the time was that of the gauge. When the report of the Royal Commission on this subject was issued, Mackay wrote a leader (GA 1846.02.23) that endorsed uniformity of gauge as something obviously desirable. However, there is no indication he was prepared to ask for government to force existing lines to standardize. Instead, he likely had it in mind that in the future Parliament should only approve projects on some single gauge. (He was in favor of the Brunel broad gauge, and not the standard gauge recommended by the Commission, though.) Such moves were generally acceptable even to the most devoted laissez faire proponents.

Less than a month later, in mid-March 1846, we find a clear sign of a substantial change in Mackay's opinions. In a leader summarizing Parliamentary actions, Mackay wrote about a motion made by James Morrison in the House of Commons (GA 1846.03.16):

Mr. Morrison, who has just published a very able pamphlet on Railways, is in advance of the Government, and we think of the public mind, in his views; ... [The time for Morrison's motion] will come, however. People are beginning to be aware of the fact, that in France they have managed the thing better than we have; and that a new monopoly is springing up amidst us when the old one is expiring, which will inflict serious injury, unless timely precautions are taken. That every line of railway ought, after a certain number of years, to become the property of the nation, begins to be acknowledged, and although it may be too late to apply the principle to lines already conceded, it is not too late to argue this great question thoroughly in all its bearings, before any new acts are passed. The subject, we may depend upon it, will grow in importance, and will force itself to a solution.

Now we discover serious concern about monopoly, which was very natural for a Liberal of that era, but had been totally absent in the railway context from Mackay's writings in the Argus during the preceding year. We also find a major (but not complete, as will be seen) departure from the previous unrestrained enthusiasm for private enterprise in the desire for railways to be owned by the government. This occurred at the same time that Mackay called on the government to slow the pace of railway expansion.

What caused Mackay to change his views? It was probably not any single thing, but a combination of events and changed circumstances. The heady days of creating Glenmutchkin lines out of thin air were gone, and people were beginning to think of the future on a longer time scale. Three intertwined notions were very prominent, and all three were embraced by Mackay. In retrospect, we can say that all three were delusions.

The first notion, discussed in the previous section, was that Britain did not have the capital to build all the lines that were likely to be approved by Parliament under normal procedures. The second popular notion, which was cited above in the references to Morrison's pamphlet [36], was that Britain should not give unconditional perpetual rights to railway companies, but should instead adopt the system then in place in France. There, private companies were expected to build and operate railways, but after some decades had to turn over everything to the government. In most cases, it appears the proponents of this approach did not mean for the state to operate the railways once it took them 
over. This was a period when government was widely regarded as inefficient and corrupt, and the Marquis of Lansdowne, who in mid-1846 became the Lord President of the Privy Council, declared that "[i]t is universally admitted that Governments are the worst of cultivators, the worst of manufacturers, and the worst of traders." What everybody seemed to be implicitly assuming (cf. [36], p. 20) is that railways would be leased for extended periods of time. There are obvious problems with such an approach, in terms of capital improvements and maintenance (and it did not work very well in practice in France!), but it was familiar to the British, since that is how much of their real estate industry operated. The huge agricultural estates possessed by the aristocracy were not run centrally, but were leased in more manageable parcels for terms of a decade or two. Were such a system to be adopted for railways, the rules and prices could be reset at each lease expiration. This would preserve the sanctity of contracts that was cherished by the ruling elite, and yet provide some control over the operations of the new infrastructure. In 1846, the most prominent advocate of introducing such a policy in Britain was Morrison. He was a very interesting person who is little known today; for a biography see [12,41] and for more details on his involvement in economic policy debates see [37]. His main concern throughout his career was about the level of railway charges. He was an enthusiastic supporter of railways as a technological and economic innovation, but was concerned that railways would keep their charges so high as to strangle the economy. Hence he fought for a range of measures to prevent such an eventuality.

The third notion (closely related to the second) that captured the attention of Mackay and the public was that of using profits from railways to pay for the national debt. As was mentioned in Section 2, that debt was a national obsession. Britain's victory over France in the Napoleonic wars was widely attributed to the possession of a far better financial system. But that system had been stressed to the utmost, and national solvency was a frequent topic for debate. Various nostrums for alleviating this oppressive load were bruited, and one that attracted considerable attention was to use the rapidly growing stream of railway profits for that purpose. This notion was discussed prominently in Morrison's pamphlet [36], and was used to support his argument for only allowing limited-term leases of railways. Morrison's proposal was that the French system be applied to new lines. Once their leases expired, the profits from operations would be redirected towards paying for the national debt. But that scheme would still require waiting some decades for the expirations of the leases. Some observers felt that was too long. In the same March 23, 1846 leader that was cited before, Mackay devoted an unusually large space to a presentation of selections from an alternate proposal for faster action:

... we reprint the details of a grand scheme of buying up all present railways for the national account, and of making all future railways the property of the nation after a certain period, and on certain conditions. It has been forwarded to us from Birkenhead, and bears the signature of Charles Edward Herbert Orpen, M.D. member, apparently, of half-a-hundred different societies, learned and unlearned. The writer himself seems to indulge in the most sanguine hopes that his scheme will ultimately be adopted; in fact, he is certain of it, because, he says, "no other plan can ever be devised so simple and effectual." Without sharing the hopes of this ingenious 
gentleman, and somewhat wondering where the money is to come from, "out of the present and future surpluses of the annual revenues of the Empire," to buy up all the existing lines, we must submit that, extravagant as his scheme may appear, it is far from being either uninteresting or unimportant; and that if we could benefit our posterity in a manner so extraordinary, not only without injury, but with positive advantage to ourselves, the projector of the scheme would deserve the gratitude of the present and all future generations....

Clearly Mackay viewed Orpen as a slightly ludicrous figure, and realized there was a huge obstacle to Orpen's scheme, that of finding the money to purchase existing railways. But the attraction of an easy way to deal with the national debt seemed so great, that Mackay was willing to give it a generous amount of space in the Argus.

All three of these key notions were grounded in an extremely rosy view about the future of railways, as was already discussed in the previous section. The railway industry, with gross revenues of $£ 6.1$ million in 1845 , was expected within a decade or so to generate net profits of £28 million per year. Morrison's argument that investors would not mind eventually giving up their railway properties to the state was also based on the assumption that profit rates were going to be so high, that their abrupt cessation after 40 years, say, as was envisaged in many of the French deals, would not affect decisions to invest.

The railway leader from April 23 serves as a nice introduction to Mackay's attitudes towards railways in early 1846. In that leader, Mackay complained that in sanctioning the early railways, Parliament had not insisted on getting them to provide free carriage for mail. He was a stickler for "the sanctity of contracts," as were most Liberals. "The mistake has been made, and the nation must submit. It would not be right to make a ex post facto law, and mulct these companies against their will," he wrote. However, he felt the mistake would be easy to rectify simply by insisting that future railways accept free mail carriage as a condition for getting their charters:

The great trunk lines at present are not direct lines, as every traveller knows; and it is easy enough to foresee that when the panic of 1845 and 46 is forgotten; when trade has revived, and speculation is free again to enter, with more wisdom than heretofore, into the full development of which the railway communication of these kingdoms is susceptible, that direct lines will be started to compete with the roundabout ones at present in existence.

This quote perfectly captures several of Mackay's delusions, about the viability of "direct" lines, about much greater expansion of the railway network in the near future, and about profitability of those lines (since how else could one expect speculation to revive?). This quote also shows Mackay's abiding faith that competition was the way to solve almost all problems in the marketplace. But for this faith to be tenable, there would have to be more waves of extensive railway construction, to make the old lines obsolete, and thus to compensate for what he felt were the mistakes in those old charters.

During the spring of 1846, even though the Corn Laws wars were still going on and absorbing much of Mackay's attention, he wrote a number of leaders about railways. Some were about the threats to the beauty of Glasgow by another proposed cross-harbor railway link ("a monstrous insult to the intelligence of this city," as one leader put it, GA 
1846.03.19), while others showed increasing concern about railway monopolies. Thus he applauded the appointment of a Parliamentary committee to study railway amalgamations (GA 1846.03.26), because of the need to ensure

that, in extricating ourselves from the fangs of one great Monopoly [of protectionists with their Corn Laws], we have not run into the very jaws of another equally hungry. The great Railway Companies are impervious enough even now, when they are not entirely out of the reach or fear of competition; and it requires but little sagacity to calculate what they would do if six or seven of them had the whole control of the great trunk lines of the country, and all their branches.

Price fixing and cartels were common and legal, and there were no anti-trust laws to prevent combinations. But even without giant combinations, there were many complaints about small railways exploiting their local monopoly. There was unhappiness about insolence of railway employees, high fares, late trains, and all the minor annoyances that occur every day with all services, but which competition is supposed to cure. However, there was in most cases no competition in railway service, and so customers had no recourse. And in addition there were yet other, more fundamental, challenges to the free market expectations that were posed by railways. For example, Kostal in his detailed study [21] discusses the "Small Freight War." Railways charged high rates for small parcels, and when independent carriers assembled such parcels into bundles and tried to send them at the lower rate for bulk merchandise, railways either refused to carry them, or charged for each individual parcel, which of course meant they had to open up the bundles. (The analogies to net neutrality and Deep Packet Inspection on the Internet are obvious.) This was plainly illegal, but, as Kostal notes, "[a] long and unbroken chain of unfavourable court verdicts was of little apparent consequence to railway directors determined to get their way in the small freight trade dispute." ${ }^{33}$ Government regulation of industry was often called for, but there was little expertise in it, and strong opposition on principle, especially from Liberals like Mackay.

Mackay's attitude to markets can be judged by several positions he took. He was a strong opponent of entail, which was extremely widespread in the UK at the time, and created large real estate properties that could not be sold or divided by those controlling them. A staple of Victorian fiction, entail, along with primogeniture, was a tool for the aristocracy to preserve and enhance family positions. Mackay fought to abolish entail as a hindrance to the operation of the free market. He called entail and primogeniture "those barbarous relics of a barbarous time," complained about "[t]heir mischievous influence upon society," and urged legislative action to abolish them ${ }^{34}$. Thus he was willing to use government action to shape the law and the markets to promote what he regarded as desirable social goals. On the other hand, he was willing to tolerate some inefficiencies in the market, and refrain from having the state intervene, as is shown by the Free Church case.

A fuller understanding of Mackay's positions and of the intellectual climate of Glasgow and of the UK as a whole would require delving into various religious issues. In the interests of brevity, this is not done here, except for brief mention in two cases where it is unavoidable, that of Sunday trains, which are treated later, and of sites for Free Churches. Scotland had 
an official established church, which was distinct organizationally and doctrinally from the Church of England. In 1843, a year before Mackay's move to Glasgow, the Church of Scotland went through the great Disruption, in which a very large fraction of the members left, in a dispute over state interference in church affairs, and established the Free Church. All church real estate continued to be controlled by the Established Church, which was supported by taxes. The Free Church faced not only the huge problem of raising funds exclusively through voluntary donations, but also landlords in a very concentrated real estate market who were unwilling to sell or lease land because of religious opposition. In desperation, the Free Church attempted to persuade Parliament to pass a law that would compel landlords to do so at fair market prices. (There was no suggestion of simply taking the land, the request was for rights similar to those that railways were getting, where, if private negotiations failed, the price was decided by arbitration or by a jury.) Mackay devoted considerable thought and space in his leaders to this issue. He agreed that the real estate market was not functioning properly (GA 1846.06.15):

It is true that many of the landowners of Scotland have violated the rights of conscience by refusing sites. It is true that in forcing the ministers and their people to worship on the way-side, or on the sea-shore, they have brought discredit upon themselves, and forced men to question whether there were any inherent right of property in the soil, which would justify this negation of a resting-place upon it to the sincere men and pious Christians who merely wished to worship God after their own forms, and according to their own conscience.

However, Mackay felt that "the evil [was] curing itself, by the force of public opinion, and without any aid from the strong arm of the law," and that passing a law for the Free Church would require extending its benefits to other religions, and that would lead to many other complications and undesirable side effects. Thus he did not want government to intervene to deal with this market failure.

By the beginning of the summer of 1846, the Corn Laws war was over. Mackay and his numerous allies had won. He now directed his passion and energy towards advocacy of tax-funded and government-provided education. At that time, about half of the population of England was illiterate, and there was a wide feeling this was unhealthy for economic and social reasons. Mackay's position differed from that of many prominent Liberals, such as James Wilson of the Economist or the younger Edward Baines of the Leeds Mercury. Those two were also in favor of better education, but argued that it should be achieved by private efforts. Mackay's main contribution (aside from many leaders scattered through the years) to the debate was a series of 12 long, signed leaders in the Argus, starting on September 7, 1846, which were soon afterwards published as a pamphlet [29].

As he was about halfway through the 12 leaders on education policy [29], Mackay ran into a new issue which involved railways. It eventually ranked with Corn Laws and education in the attention and passion that he devoted to it. It was the question of Sunday trains. It touched on some very basic policy questions about a public infrastructure, so it is worth a careful look. It started out with a seemingly minor corporate governance issue. Under pressure from unhappy shareholders, all the Edinburgh and Glasgow Railway directors resigned in September 1846, and were replaced by a new team. Mackay wrote 
a leader, claiming surprise the event had not been covered much by the press, and in particular that no attention had been paid to the intention of the new directors to raise fares. He argued that "the idea ... is so preposterous, ... wonder the observation was allowed to pass unnoticed" (GA 1846.09.28). But Mackay's response was just that of a free marketer. He claimed that the Edinburgh and Glasgow Railway had done less than almost all railways in lowering transport costs, compared to the old horse-drawn coaches. Hence people would simply not pay the new fares, and would, if necessary, go back to coaches.

What really upset Mackay was another step that the directors of the Edinburgh and Glasgow Railway took soon afterwards. They stopped running passenger trains on Sundays. (The Sabbatarian movement, which makes a notable appearance in the Glenmutchkin story, was a prominent force in the UK and US at that time, and was especially powerful in Scotland.) This measure aroused vociferous protests (as well as applause from the Sabbatarian side). Mackay's response was interesting. A week after the announcement, he published a leader saying that the "[c]onsiderable indignation" that had been expressed "[was] thrown away, and that the public, who have been naturally somewhat angry and disappointed at first, [would] very soon learn to bear the infliction with patience and equanimity" (GA 1846.10.29). His stance was based on a combination of free market thinking and the fundamental laws under which railways were supposed to operate.

Railways in Britain were private enterprises, but they were subject to common carrier rules, grounded in common law, as well as specific non-discrimination provisions in their charters. Parliament was well aware that unfettered control of a vital infrastructure would be as damaging to the economy as a lack of property rights, and so restricted railways at the time it authorized them. (It was very careful not to interfere otherwise, in order not to be seen as breaking its promises and damaging the "animal spirits" of the enterprise.) Their maximal charges for different types of goods or for passenger travel were limited on the upside, and initially had to be the same, based just on mileage, for all locations and all customers. (As time went on, the logic of differential charging led to a relaxation of some of there restrictions.) Railways were in general not subject to the strict separation that applied to most canals. However, railway charters initially did envisage that their main activity would be just building and maintaining the rail ways, with carriers providing services over those rails using their own wagons and locomotives. However, railways increasingly took over all operations, and the argument of Adams in the 1844 article [1] that was cited earlier was that this should be stopped, and a strict structural separation policy should be imposed. But even without new legislation, open access to the rails was there in the law, and Mackay saw in this a free market solution to the difficulty. He claimed that private enterprise was going to solve the problem, to the detriment of the Edinburgh and Glasgow Railway shareholders. Other carriers would come and provide service over this line. "The present Company cannot refuse the use of the rails; - they cannot levy an exorbitant or prohibitive toll - its rate has been fixed by Parliament. Twopence per mile per passenger is the maximum" (GA 1846.10.29).

It is rather surprising that Mackay was so ignorant and forgetful as to suggest this solution. (He did not bring it up again, surely because some of his readers pointed out its impracticality.) The issue had come up in the late 1830s, and Parliament concluded that 
it could not enforce its laws. Mackay was working at the Morning Chronicle at the time, so should have learned about it. Not only that, but the 1844 article [1] by Adams that was reviewed favorably by Mackay did complain that

[early railway] legislation ...was of the most ignorant kind. ... a provision for competition in carriage was made, of so absurd a kind, that it could not be executed. As the secretary of one of the lines remarked to a committee of the House of Commons: "Competitors may run engines on our line - if they can; we are not bound, by law, to furnish them with either coal, water, or station room."

Thus the free market and legal guarantees of open access were not going to solve the problem of providing Sunday trains.

Over the next few months Mackay devoted an inordinate amount of space to the attempt to bring back Sunday trains. He tried reasoned arguments. He tried appealing to charity, as Sunday trains were represented as a way for the poor to visit their friends and family and get some clean fresh air away from the city. He tried theology, printing learned interpretations of the Scriptures that supported Sunday travel. He championed petitions for Sunday trains, and denigrated petitions that opposed them. He put much hope in a shareholder meeting that was to vote on Sunday trains, and then explained away the negative result as the outcome of vote manipulation, something of "no moral worth." There was plenty of sarcasm, and demonstrations of the hypocrisy by the opposing side. Thus Mackay reported with great glee that the Edinburgh and Glasgow Railway was forcing its employees to carry out repairs on Sunday, and that the Chairman of the Board of this line traveled by train on Sunday (on another line). On several Sundays a count was made of the number of carriages that brought rich worshippers to Glasgow churches. It is not clear whether Mackay helped organize the count, but he used it to argue that the 215 carriages found on one occasion implied that at least 430 servants had been forced to "desecrate the Sabbath," as opposed to at most 20 who would have been required to provide trains between Glasgow and Edinburgh (GA 1847.05.17). But it was of no avail. Mackay appeared to realize this early on, and he broke his laissez faire principles by calling on Parliament to force railways to provide Sunday trains.

Mackay argued early on that stopping Sunday trains was illegal. But he never explained just how, and nobody else managed to do it either. Mackay did fume that railways were not "a private concern," but "a national concern - over which, for national purposes, rights have been granted to a trading company" (GA 1846.12.14). That was certainly how many people felt. After all, Parliament engaged in wholesale violations of landowners' property rights in order to enable the construction of railways, and did so in the name of the public good. But that is not what the letter of the law said, and now the nation was stuck with a private monopoly (or at least many small local monopolies). Many of the opponents of railways in the 1830s had warned about this danger. Steam carriage advocates, for example, argued that their technology should be preferred to railways, since it could preserve the traditional system of neutral turnpike roads, with many independent carriers providing the advantages of the competitive market of Adam Smith. However, railway technology won, and led to local monopolies that did not deliver what Mackay felt was essential. So he broke with his principles, and decided government intervention was necessary. In commenting on 
a petition calling on the Edinburgh and Glasgow Railway to restore Sunday trains, he wrote (GA 1847.02.22):

We would urge upon the public the necessity of discontinuing these petitions to the Directors. They are of no use. Let the petitions be sent to Parliament. Mr. Hume [a prominent politician who championed the cause of Sunday trains] will take care of them, and the House [of Commons] will listen to their prayer. ... The result will most assuredly be, that every railway at present existing, and hereafter to be made, and not alone the Edinburgh and Glasgow line, will be bound by the law of the realm to carry the mail on Sunday, and with the mail to provide accommodation for passengers. All future wrangling will thus be stopped; ...

As it turned out, Parliament did not act, and Sunday trains were not restored to the Edinburgh and Glasgow Railway for another two decades. (In the meantime, other lines provided trains between Edinburgh and Glasgow, but by circuitous routes.) But the incident is illustrative of how Mackay reacted when his free market beliefs collided with reality. In the case of mail carriage by trains, he argued that "[t]he mistake has been made, and the nation must submit. It would not be right to make a ex post facto law." But here he apparently decided that his preferred free market solution, of waiting for a new wave of railway expansion, and imposing the desired conditions only on new entrants, would take too long, and that immediate intervention was justified.

Mackay did not depart very far from laissez faire principles, only in exceptional railway situations. The March 8, 1847 issue is an excellent illustration of just where he felt the government should step in. One leader enthusiastically supported Parliamentary intervention to compel running of Sunday trains and confidently expected it to occur soon. Another leader, about obtaining sites for the Free Church, suggested that Parliament "should not be rashly invoked to meddle" in a complicated question, even if there was a market failure. And yet another leader engaged strongly in a last-ditch effort to stop the Ten Hours Act, "the dangerous and purely experimental" measure, full of "perils to which it was likely to expose" the UK. On the other hand, there was no leader about a fundamental issue that Mackay and most of compatriots were taking for granted by the 1840s. This was that Parliament should continue to use the right of eminent domain to take land from private owners to give to private railways. There were still a few people, most prominently Colonel Sibthorp in the House of Commons and Lord Brougham in the House of Lords, who complained of such outrageous violations of "the sacred right of property," but they were a small minority. The consensus among the ruling elite was that railways were a necessity for the nation, and property rights had to give way, even if a private monopoly was the result.

Even while Mackay was engaged in his national education and Sunday trains crusade, the Irish Famine was unfolding, and so was a similarly severe food crisis in the Scottish Highlands. The poor harvest of 1845, which provided ammunition for Mackay and other free traders in the war against Corn Laws, was nowhere near as terrible as had been feared. But a year later, the potato crop was an almost total loss, and around a million people died in Ireland as a result. Mackay devoted considerable space to this tragedy in both the news columns and the leaders of the Argus. It would take a long time to describe 
his evolving perceptions, attitudes, and policy recommendations, but it seems fair to say that although by today's standards he could be called callous, he was more receptive to government intervention than his fellow Liberal James Wilson of the Economist [9]. As in the rest of the paper, let us concentrate on Mackay's views on railways, as those did come up in the Irish Famine discussions.

Railway history literature has many citations to Disraeli's novel Endymion. Published in 1880, shortly before his death, it was a fictionalized history of British politics of the second quarter of the 19th century. What made it noteworthy for those interested in railways were the stirring passages on how railways came out of nowhere to pull the British economy out of the deep depression of the early 1840s. Those passages, although written in the 1870s, were based on what Disraeli and many of his political allies were saying in early 1847. As Parliament reconvened that year, and began to consider measures for the relief of the famine in Ireland, railways were offered as a key solution by Lord George Bentinck, with the support of Disraeli and others. The proposal was for a large government loan to railway companies in Ireland, and it was accompanied by extensive panegyrics to railways as agents of economic development, panegyrics that were echoed decades later in Disraeli's Endymion. The opponents, on the other hand, did not deny the wonderful effect of railways, but came out with their panegyrics to pure private enterprise and castigations of government inefficiency and corruption. Their main question was why private initiative could not build those Irish railways with private capital, if they were to be as profitable as Bentinck and Disraeli claimed.

Mackay at first seemed to be willing to consider the Bentinck proposal, although with clearly detectable doubt and hesitation (GA 1847.02.08). But very soon he turned against it. He declared that the Chancellor of the Exchequer, who argued against the proposal, was right to "characteriz[e] it as a project got up, not for the benefit of the destitute people of Ireland, whom it would not relieve, but for the special behoof of "destitute shareholders" and railway jobbers" (GA 1847.02.15). As the Chancellor of the Exchequer explained in the speech cited by Mackay, there were various practical objections to the Bentinck scheme. It would take time for the construction to start, as first the land would have to be acquired, contracts let, etc., whereas the famine emergency required immediate action. Railways would be built in the most prosperous areas, and thus far from those in greatest need. And so on. But there may have been other, more political reasons for Mackay's negative reaction. Bentinck and Disraeli undoubtedly hoped to lessen the taxes on landowners that were going to be levied for famine relief, and also to bring back Corn Laws. (Their argument, as well as of most Protectionists, was that the way towards a prosperous future was to have high wages and high prices.) And that was counter to Mackay's views. In any event, in spite of his enthusiasm for railways, Mackay did not accept them as solutions of the Irish Famine problem.

\section{Conclusions}

There are many similarities between Mackay's time and our own. Economies emerging from a deep recession today and an unusually deep depression then. Concerns about unemployment, lack of skills, inequality, even hunger, as well as about idle capital, are almost 
identical. There are also differences, of course. The 1840s offered a convincing promise of high payoff from wide deployment of railways, a promise that, with the usual embellishments by promoters and enthusiasts like Mackay, led to the Railway Mania. What followed was ruin for investors, but also a significant boost for the economy, greatly facilitating the "Great Victorian boom," the unprecedented quarter of a century of rapid economic growth that transformed British economy and society. Currently we do not have anything of equivalent promise to energize society.

Leaving aside far-fetched speculations, the best concrete lessons we can draw from Mackay's story are about the growth of delusions in society, and their role in stimulating economic activities. Extraordinary Popular Delusions declared ([27], 1841 ed., vol. 1, p. 3) that

Men, it has been well said, think in herds; it will be seen that they go mad in herds, while they only recover their senses slowly, and one by one.

While one can quibble about this claim, as many bubbles end in sudden crashes that bring most of the human herd to their senses almost at once, the behavior of British investors in the Railway Mania does fit this pattern. As is shown by Fig. 1, their enthusiasm for railway expansion grew to its peak in about a year, and then took about four years to be disspelled, as cold reality forced them to capitulate "one by one." Mackay himself was a leader of the herd, at least to the point in mid-1847 when we lose track of his opinions. Always an enthusiastic supporter of technological and economic progress, as well as of free markets, he started out with moderately cautious expectations in the fall of 1844, but then developed into one of the most rabid proponents of railway expansion. He fully partook of the principal delusion of the Mania, namely that a huge expansion of the railway network could be carried out with profit to both the nation and investors. He never wavered in this belief, even as events and opinions of others led to him to modify some of his positions and fall into other delusions. He did not recover his senses during his time at the Argus.

Mackay's blindness to the fatal defect of the Mania was essentially universal among his compatriots, and appears common during financial manias, part of the conviction that "this time is different" $[39,45]$. It is notable that while he put serious thought and effort into combating the poetry of Wordsworth and the warnings of The Times that he perceived as hostile to rapid railway expansion, he did not even bother refuting the (relatively rare) warnings that the new lines would be unprofitable. He apparently did not think they were credible enough to be worth attacking. Can bubbles be recognized before they they inflate too far? That is still an open question. However, it is clear that without searching for bubbles, one will not find them. Most observers of the past decade did not even look, and neither did Mackay.

Mackay's enthusiasm for railway expansion was likely sustained from 1846 on by the prospect that the bountiful profits from this industry would relieve the burden of an oppressive national debt. This enthusiasm was probably also reinforced by his vision of being able to control undesirable behavior of an infrastructure monopoly through modifications of charters of the expected waves of new entrants. This vision enabled Mackay to stick to his laissez faire views. It is amusing that it was only the Sunday trains issue that led him to abandon his cherished doctrine and call for government intervention. 
Mackay's story helps explain why British investors were so slow to recognize and acknowledge their impending doom. At the height of the Mania, in the fall of 1845 , the most prominent skeptics, such as James Morrison, James Wilson, and The Times, were warning investors that fast railway expansion would lead to declines in share prices through the pressure of capital calls and the disruption of financial markets. When share prices started to decline, as they predicted, the cause for the decline was assumed to be the one they had presented, namely the pressure of the "calls," the demands from railways for money from shareholders. But the fundamental problem of the industry was that the new projects were not going to be profitable. Even after calls stopped, railway share prices remained at the depressed levels seen in 1849-50 in Fig. 1. The decline in prices visible in that figure was likely the result of increasing numbers of investors guessing or deducing that profits were going to disappoint. But public discussion was fixated on the issue of calls, and the realization of the size of the investment disaster was slow to come [40].

Mackay was more gullible than most, as the discussion of Mesmerism and other topics in this paper demonstrates. However, even far deeper and more perceptive of his contemporaries, such as James Morrison and James Wilson, also suffered from the main delusion of the Mania. Railways were not just investments with promising profit prospects for individual investors, they were a dazzling new technology that was transforming society, "annihilating time and space," in a phrase that was heard frequently at the time. Bentinck, Disraeli, and others credited them during the discussions of how to relieve the Irish Famine with having miraculously pulled Britain out of the deep depression of the early 1840s. Few were able to resist the siren song. The one who managed to stay sober the best was Dionysius Lardner, see [37]. His 1846 survey of the railway industry [22] pointed out most of the fatal defects of the Railway Mania. Lardner had once been an insider in the British scientific establishment, but then disgraced himself and ended up spending several years traveling in the U.S. At the time of the Mania he was living in Paris. His varied experiences, status, and location likely all contributed towards maintaining a distance from the British herd, and enabled him to see what was wrong.

The story of Mackay's extraordinary popular delusions is amusing. But it is also instructive. It shows how crowd effects and personal biases influence decision making in times of rapid change and poor information. It suggests that it would be worthwhile to investigate the reactions of various other individuals from the Railway Mania period. There seemed to be a great reluctance among participants in this episode of extreme investor exuberance to even acknowledge their involvement in it and to analyze what happened. As just one example, John Stuart Mill's publications and correspondence do contain a few interesting passages about railways, but we have to go to archival sources, as in [6], to learn that he was involved in some of the most speculative railway projects with a Glenmutchkin flavor. More investigations, especially in cases, such as that of Charles Mackay, where we can find extensive contemporary documentation about particular individuals' thoughts and writings, could help illuminate the Railway Mania and lead to a better understanding of manias in general. 


\section{Notes}

${ }^{1}$ Mackay's History of London, published in 1838, has several pages on the South Sea Bubble ([30], pp. 362-66), a brief preview of the far more extensive coverage provided in 1841 in Extraordinary Popular Delusions. History of London also has a discussion of the mania of the mid-1820s ([30], pp. 459-61), in tones similar to those used for the South Sea Bubble. Thus Mackay was aware of the first large investment mania of the 19th century in Britain, even though his first-hand experience with it had surely been limited, as at the time he had been a boy living near London. Further, he shared the opinion, very common in Britain in the 1830s and 1840s, that this mania was comparable in its intensity and destructive effects to the South Sea Bubble. However, he did not cover this topic in Extraordinary Popular Delusions. By the time of the mania of the mid-1830s, Mackay was working on the editorial staff of the Morning Chronicle, one of the leading London dailies, so had extensive exposure to the coverage of that episode. Yet he did not describe it in the History of London of 1838, nor in the Extraordinary Popular Delusions of 1841, even though the latter book had extensive coverage of some recent trendy ideas he classed among delusions, such as Mesmerism.

${ }^{2}$ According to the Return of Number of Persons employed on Railways ..., May 1847, Parliamentary Papers 1847 (579) LXIII.101. in May 1847 there were 256,509 workers employed in constructing new railways, as well as 47,218 working on those in service. An estimate from the early 1840s showed the British Army (including its artillery branch) at about 132,000, [50]. The British Navy (including Marines) had about 44,000 men in service. There was also a force of about 181,000 in India, but they were officially employed by the East India Company, and paid out of Indian revenues. The regular Army was frequently used for domestic operations, since police forces were small by modern standards. The population of the UK, which included all of Ireland, was about 28 million.

${ }^{3}$ Published in the Perthshire Courier, Nov. 20, 1845, p. 3, and reprinted in the Glasgow Argus, Nov. 24, p. 4 and in the Glasgow Herald, Nov. 21, p. 2.

${ }^{4} \mathrm{~J}$. Thomas claimed that Mackay's leader (which he did not connect to Mackay) appeared " $[\mathrm{o}] \mathrm{n}$ the day after the October 'Blackwood' containing the lampoon was on sale" ([51], p. 19). This seems questionable. The Morning Chronicle of Sept. 29, 1845, p. 16, had an ad announcing the October issue, and so it is likely that it was on sale that day.

${ }^{5}$ The railway engineer William Bridges Adams wrote in 1845 that eventually "horse and foot transit shall be nearly extinct," and that "every mile of highway will ultimately be replaced by two miles of railway" [2]. Britain had around 150,000 miles of public roads of all kinds. Mackay reviewed the Adams article very favorably, claiming that "the observations on land steam conveyance, to supersede the necessity of horses, is especially worthy of notice," Glasgow Argus, Oct. 16, 1845, p. 6.

${ }^{6}$ P. W. Banks, [5], pp. 98-99, criticized Adams' views as "a specimen of the wild fantacies that in this season of railway frenzy haunt the brains of even clever and intelligent men!"

${ }^{7}$ Report of Proceedings of Railway Dept., 1858, Parliamentary Papers 1859 Session 2 [2560] XXVII.637 p. xi. The returns on total capital were not a complete disaster, as over that decade they averaged $3.55 \%$. 
${ }^{8}$ Approximate dates can be ascertained from the Bentley ads in the Athenaeum. The first two volumes are listed there on Oct. 16 as to be published in October, a week later they are listed in the category "just ready" (but not among books already published, which were listed separately). The third volume is listed in an ad in the Dec. 25 issue as among books that "Bentley will publish ... immediately," and the Jan. 1, 1842 ad lists it among books that Bentley "has just published."

${ }^{9}$ However, it was not shabby, either. For the History of London, the payout came to $£ 50$, while the Morning Chronicle and the Glasgow Argus paid him about $£ 400$ per year.

${ }^{10}$ For extensive information about book publishing in the early Victorian times, see the book [14] about Mackay's publisher. Searches in the Bentley archives [14,44] might uncover exact figures for sales of Extraordinary Popular Delusions.

${ }^{11}$ For example, an ad from Bentley on p. 8 of the Morning Chronicle of Feb. 28, 1845, devoted to just this one work, lists it as "Now ready." Tricks of that kind were common.

12 The Times, Nov. 19, 1841, p. 5. A very positive review was published by the Era, Nov. 28, 1841, p. 6. Other reviews are referenced in [25]. Still others were printed in the Athenaeum, in its issues of Nov. 6, 1841, pp. 848-851, Jan. 29, 1842, pp. 104-106, and Feb. 12, 1842, pp. 140-142, in the Monthly Review, Dec. 1841, pp. 493-504, and (for the second edition) in the Daily News, March 25, 1852, p. 2.

${ }^{13}$ This is based on extensive reading of the literature as well as searches in online databases of books, magazines, and newspapers from that period. Two examples of citations from Mackay's work were the articles "Railways and metropolitan improvement" and "The Bank Charter Act. Currency principles" that appeared in the Westminster Review, June 1846, pp. 241-246 and July 1847, pp. 412-466, respectively. Another is the article "The railway speculation mania" in the London Journal of Nov. 1, 1845, pp. 115-16.

${ }^{14}$ The entire leader section of the June 17, 1847, issue was devoted to this. See also Mackay's rejoinder, in a letter in the Glasgow Herald, June 18, 1847, p. 2.

${ }^{15}$ Circulation figures for the Argus and other papers are taken from Return of Number of Stamps issued at One Penny to Newspapers in United Kingdom, 1837-50, Parliamentary Papers 1852 (42) XXVIII.497. These figures are also in [7].

${ }^{16}$ For example, the article "Mesmeric conversazione" in the Oct. 17, 1844 issue, p. 2, the London letter on Nov. 25, 1844, p. 2, the reprint from the Athenaeum on Nov. 8, p. 4, and the reprint from the Medical Gazette on Dec. 5, p. 4.

${ }^{17}$ This claim by Mackay suggests he may have been the writer of reports in the Morning Chronicle on Sept. 7, 1841, p. 4; June 27, 1844, p. 6; and July 2, 1844, p. 5.

${ }^{18}$ See the article from the Carlisle Journal, reprinted in GA 1844.11.07, p. 1.

${ }^{19}$ The long opinion piece, "Kendal and Windermere Railway. Poetry against the world." from the Morning Chronicle, Oct. 23, 1844, p. 3, was reprinted in GA 1844.10.28, p. 1. An article from the Carlisle Journal appeared in GA 1844.11.07, p. 1. The Milnes sonnet, "Projected railways in Westmoreland," was published in GA 1844.11.28, p. 4. It is available, under the title "Answer to Wordsworth's sonnet against the Kendal and Bowness Railway," in ([34], pp. 227-8). Some publications give as the source of this poem the Whitehaven Herald of Nov. 30. The Argus publication precedes that by two days. 
${ }^{20} \mathrm{An}$ interesting question is whether investors or Parliament could have been persuaded by any evidence and methodology that was available at the time. The Railway Times of Nov. 30, 1844, p. 1410 had a letter from an opponent of the Kendal and Windermere Railway. This writer did predict financial disappointment, in that that costs would be higher and revenue lower than promoters were predicting, but did not provide any data. At it turned out, by 1852, revenues were not far from the expected levels, and it was only the high construction costs that made this project a disappointment.

${ }^{21}$ GA 1844.10.31, p. 4. It was drawn from The Times, Oct. 28, 1844, p. 3.

${ }^{22}$ GA 1845.07.03, p. 3. First published in The Times, July 1, 1845, p. 4.

${ }^{23}$ The reprints were from the Sept. 13 issues, pages 6 and 4, respectively.

${ }^{24}$ These leaders appeared on Sept. 18, Sept. 29, Oct. 2, Oct. 20, Oct. 23, Nov. 6, Nov. 10, and Dec. 8. Some were not printed among leaders, but they had the same title and tone as the others in the series, and so are included in the listing.

${ }^{25}$ It seems likely that, in common with most observers and investors of that period, Mackay overestimated the importance of long distance traffic. This neglect of the importance of locality of traffic, common through centuries, is discussed in [37].

${ }^{26}$ The Scottish Western Railway was merged into the Scottish Grand Junction Railway at the end of October 1845. The latter line, which was involved in the battle between the the followers of the Duke of Montrose and of the Marquis of Breadalbane that was mentioned in the Introduction, was successful in getting Parliamentary approval in 1846. However, construction never started, and the company was dissolved in the early 1850s.

${ }^{27}$ GA 1845.11.10. The Leeds Mercury piece was from Nov. 8, p. 4.

${ }^{28}$ Reprinted in GA $1845.12 .15,1845$, p. 1. They were from The Times, Dec. 10, p. 3, and the Morning Chronicle, Dec. 11, p. 5.

29 The Times, April 23, 1846 , p. 7.

${ }^{30} \mathrm{~A}$ few days after the March 20 meeting, James Watson, the Chairman of the Glasgow Stock Exchange, gave a speech that was published right afterwards as a pamphlet [54] that was cited favorably by Mackay (GA 1846.04.02). Watson came up with similar analysis and recommendations as the meeting the preceding week.

${ }^{31}$ This may not be regarded as a good comparison, since most people were very poor, and the middle and upper classes were small. The Brontës, living on about $£ 200$ per year, which by this standard was equivalent to about $\$ 500,000$ per year, were lower middle class, while Charles Darwin and John Stuart Mill, who were spending around £1,000 per year, or comparable to about $\$ 2.5$ million, were only in the upper middle class.

${ }^{32}$ GA 1845.11.10. The Examiner leader was published on Nov. 1, p. 689.

33 [21], p. 214. Mackay does not appear to have treated this subject in his leaders, but the editor of the Argus who preceded him did, for example in a leader in GA 1844.03.07.

${ }^{34}$ There were many leaders on this topic, the quotations are from GA 1846.03.09. A year later, after victory over Corn Laws, Mackay wrote on April 1, 1847, p. 2, that the "natural consequence of Free Trade in Corn is Free Trade in Land." 


\section{Acknowledgments}

The many individuals and institutions that assisted in the project on technology bubbles from which this paper is derived are listed at $\langle$ http://www.dtc.umn.edu/ odlyzko/doc/maniaack.html . Special thanks are due to the University of Guelph Archives, whose copy of the Glasgow Argus was extremely valuable in the research.

\section{References}

1. W. B. Adams, "Railway administration and improvement," Westminster Review, vol. 42, Sept. 1844, pp. 1-80.

2. W. B. Adams, "Railway improvement," Westminster Review, vol. 44, Sept. 1845, pp. $225-258$.

3. R. D. Altick, "Nineteenth-century English best-sellers: A third list," Studies in Bibliography, vol. 39, 1986, pp. 235-241.

4. W. E. Aytoun, "How we got up the Glenmutchkin Railway, and how we got out of it," Blackwood's Edinburgh Magazine, vol. 58, no. 360, Oct. 1845, pp. 453-466. Available online at $\langle$ http://www.dtc.umn.edu/ odlyzko/rrsources/index.html $\rangle$.

5. P. W. Banks, "Of railways," Part 2, Fraser's Magazine, vol. 33, Jan. 1846, pp. 97-113.

6. K. Brown, "John Stuart Mill and the Railway Mania of 1845," Railway Gazette, Aug. 22, 1941, p. 185.

7. K. Cameron, "Finance, politics and editorial independence in the early Victorian provincial press: The case of the Glasgow Argus 1833-47," Publishing History, vol. 5, 1979, pp. $79-103$.

8. R. M. W. Cowan, The Newspaper in Scotland: A Study of its First Expansion, 18151860, George Outram \& Co., 1946.

9. R. D. Edwards, The Pursuit of Reason: The Economist 1843-1993, Hamish Hamilton, 1993.

10. R. B. Emmett, ed., Great Bubbles: Reactions to the South Sea Bubble, the Mississippi Scheme and the Tulip Mania Affair, 3 vols., Pickering and Chatto, 2000.

11. P. M. Garber, Famous First Bubbles: The Fundamentals of Early Manias, MIT Press, 2000.

12. R. Gatty, Portrait of a Merchant Prince: James Morrison, 1789-1857, Pepper Arden, 1977.

13. A. D. Gayer, W. W. Rostow, and A. J. Schwartz, The Growth and Fluctuations of the British Economy, 1790-1850: An Historical, Statistical, and Theoretical Study of Britain's Economic Development, 2 vols., Oxford Univ. Press, 1953.

14. R. A. Gettmann, A Victorian Publisher: A Study of the Bentley Papers, Cambridge Univ. Press, 1960.

15. A. Goldgar, Tulipmania: Money, Honor, and Knowledge in the Dutch Golden Age, Univ. Chicago Press, 2007.

16. The Goldman Sachs Suggested Reading List, Quant Network, downloaded April 10, 2011. 〈http://cdn.quantnet.com/wp-content/uploads/2010/11/GoldmanSachs-Suggested-Reading-List.pdf $\rangle$. 
17. J. Grant, The Newspaper Press: Its Origin, Progress and Present Position, vols. 1 and 2: Tinsley Brothers, 1871. 3rd vol.: George Routledge and Sons, 1872.

18. J. Grant, Bernard M. Baruch: The Adventures of a Wall Street Legend, Simon and Schuster, 1983.

19. W. E. Hickson, "Railway investment," Westminster Review, vol. 44, Dec. 1845, pp. 497-521 and 522 .

20. J. Hoppit, "The myths of the South Sea Bubble," Transactions of the Royal Historical Society, vol. 12, 2002, pp. 141-165.

21. R. W. Kostal, Law and English Railway Capitalism, 1825-1875, Oxford Univ. Press, 1994.

22. D. Lardner, "Railways at home and abroad," Edinburgh Review, vol. 84, no. 170, Oct. 1846, pp. 479-531. Available online at $\langle$ http://www.dtc.umn.edu/ odlyzko/rrsources/ $\rangle$.

23. K. Ledbetter, Tennyson and Victorian Periodicals: Commodities in Context, Ashgate, 2007.

24. M. Lewis, The Real Price of Everything: Rediscovering the Six Classics of Economics, Sterling, 2008.

25. P. M. Logan, "The popularity of Popular Delusions: Charles Mackay and Victorian popular culture," Cultural Critique, no. 54, Spring 2003, pp. 213-241.

26. C. Mackay, A History of London from its Foundation by the Romans to the Accession of Queen Victoria: With Some Account of the Progress of its Institutions, and Sketches of the Manners and Customs of the People in Early and Later Times, John W. Parker, 1838.

27. C. Mackay, Memoirs of Extraordinary Popular Delusions, 3 vols., R. Bentley, 1841. Revised version, under the title Memoirs of Extraordinary Popular Delusions and the Madness of Crowds, published in 1852.

28. C. Mackay, Voices from the Crowd; and Other Poems, W. S. Orr, 1846.

29. C. Mackay, The Education of the People, and the Necessity for the Establishment of a National System: In a Series of Letters to Viscount Morpeth, William Lang, 1846.

30. C. Mackay, Street Tramways for London, Their Utility, Convenience, and Necessity, with Some Remarks on the Working of Street Railways, in the United States and Canada, P. S. King, 1868.

31. C. Mackay, Forty Years Recollections of Life, Literature, and Public Affairs. From 1830 to 1870, 2 vols., Chapman \& Hall, 1877.

32. C. Mackay, Through the Long Day: Or, Memorials of a Literary Life During Half a Century, 2 vols., W. H. Allen \& Co., 1887.

33. J. R. McCulloch, Statements Illustrative of the Policy and Probable Consequences of the Proposed Repeal of the Existing Corn Laws, ..., 3rd ed., Longman, Orme, Brown, Green, and Longmans, 1841.

34. R. M. Milnes, Selections from the Poetical Works of Richard Monckton Milnes, Lord Houghton, John Murray, 1863.

35. B. R. Mitchell, British Historical Statistics, Cambridge Univ. Press, 1988.

36. J. Morrison, Observations Illustrative of the Defects of the English System of Railway Legislation, and of its Injurious Operation on the Public Interests; With Suggestions for its Improvement, Longman, Brown, Green, and Longmans, 1846. 
37. A. M. Odlyzko, "Collective hallucinations and inefficient markets: The British Railway Mania of the 1840s," manuscript available at $\langle$ http://ssrn.com/abstract $=1537338\rangle$.

38. A. M. Odlyzko, "This time is different: An example of a giant, wildly speculative, and successful investment mania," B. E. Journal of Economic Analysis \&6 Policy, vol. 10, issue 1, 2010, Article 60, 〈http://www.bepress.com/bejeap/vol10/iss1/art60〉. Preprint available at $\langle$ http://ssrn.com/abstract $=1573974\rangle$.

39. A. M. Odlyzko, "Bubbles, gullibility, and other challenges for economics, psychology, sociology, and information sciences," First Monday, vol. 15, no. 9, Sept. 2010, 〈http://www.uic.edu/htbin/cgiwrap/bin/ojs/index.php/fm/article/view/3142/2603〉.

40. A. M. Odlyzko, "The collapse of the Railway Mania, the development of capital markets, and Robert Lucas Nash, a forgotten pioneer of accounting and financial analysis," manuscript available at $\langle$ http://ssrn.com/abstract=1625738 . A shorter version, entitled "The collapse of the Railway Mania, the development of capital markets, and the forgotten role of Robert Lucas Nash," has appeared in Accounting History Review (formerly Accounting, Business $\&$ Financial History), vol. 21, no. 3, Nov. 2011, pp. 309-345.

41. H. C. G. Matthew and B. Harrison, eds., Oxford Dictionary of National Biography, Oxford Univ. Press, 2004.

42. T. Phillips, Charles Mackay's Extraordinary Popular Delusions and the Madness of Crowds: A Modern-day Interpretation of a Finance Classic, Infinite Ideas, Oxford, 2009.

43. T. Ransom, The Mysterious Miss Marie Corelli, Queen of Victorian Bestsellers, Sutton Publishing, 1999.

44. G. N. Ray, "The Bentley papers," Library, ser. 5, vol. 7, no. 3, Sept. 1952, pp. 178-200.

45. C. M. Reinhart and K. S. Rogoff, This Time is Different: Eight Centuries of Financial Folly, Princeton Univ. Press, 2009.

46. D. Roberts, "Charles Dickens and the Daily News: Editorials and editorial writers, Victorian Periodicals Review, vol. 22, no. 2, Summer 1989, pp. 51-63.

47. P. Sharp, "'1846 and All That': The rise and fall of British wheat protection in the nineteenth century," Agricultural History Rev., vol. 58, Part 1, 2010, pp. 76-94.

48. M. Smith, ed., The Letters of Charlotte Brontë, with a Selection of Letters by Family and Friends: Vol. II, 1848-1851, Oxford Univ. Press, 2000.

49. W. Smyth, Lectures on Modern History, from the Irruption of the Northern Nations to the Close of the American Revolution, 2 vols., William Pickering, 1840.

50. W. F. Spackman, Statistical Tables of the Agriculture, Shipping, Colonies, Manufactures, Commerce and Population of the United Kingdom of Great Britain and its Dependencies; Brought Down to the Year 1843, Longman \& Co., 1843.

51. J. Thomas, The Callander and Oban Railway, David and Charles, 1966.

52. K. Tillotson, ed., The Letters of Charles Dickens. Vol. 4, 1844-1846, Oxford Univ. Press, 1977.

53. J. Ward, Railways for the Many and not for the Few; or, How to Make Them Profitable to All, Smith, Elder and Co., 1846.

54. J. Watson, A Paper on the Present Railway Crisis, William Lang, 1846.

55. W. Wordsworth, The Shorter Poems of William Wordsworth, J. M. Dent, 1907.

56. G. S. Wykoff, "Charles Mackay: England's forgotten Civil War correspondent," South Atlantic Quarterly, vol. 26, no. 1, Jan. 1927, pp. 50-62. 